$\mathrm{P}-\mathrm{B} 367$

1905

BEAN, B.

FISHES OF THE BAHAMA ISLANDS 



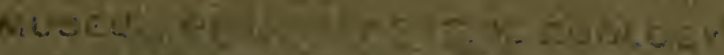

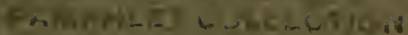

\title{
THE GEOGRAPHICAL SOCIETY
}

OF BALTIMORE

\section{FISHES OF THE BAHAMA ISLANDS}

\author{
BY
}

BARTON A. BEAN

SPECIAL PUBLTCATION FBOM

THE BAHAMA ISLANDS

BX PERMISSION OF

TEE GEOgRaPHICAI SOCIETY OF BatTIMORE 1905 


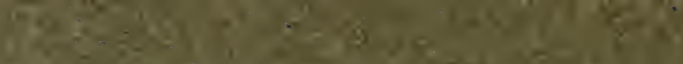

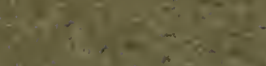

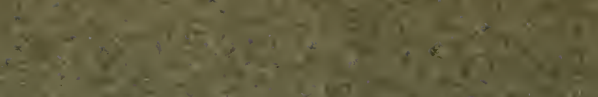

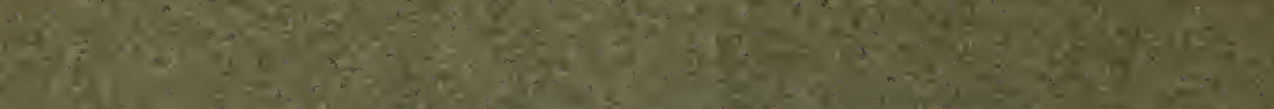

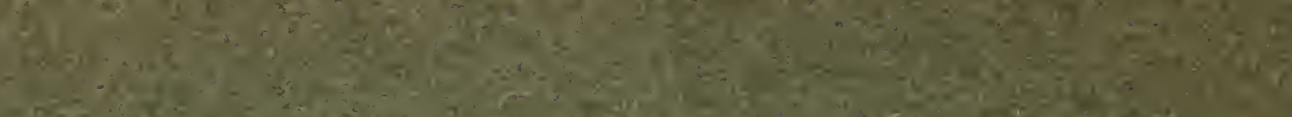

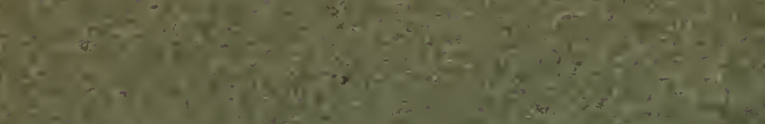

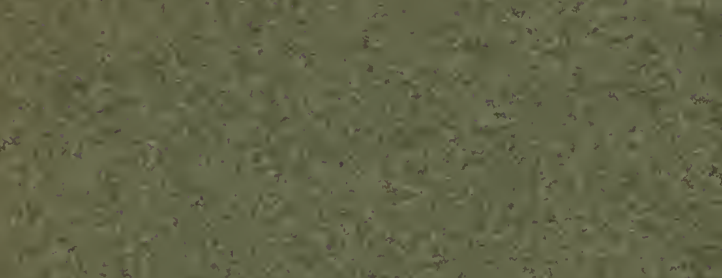

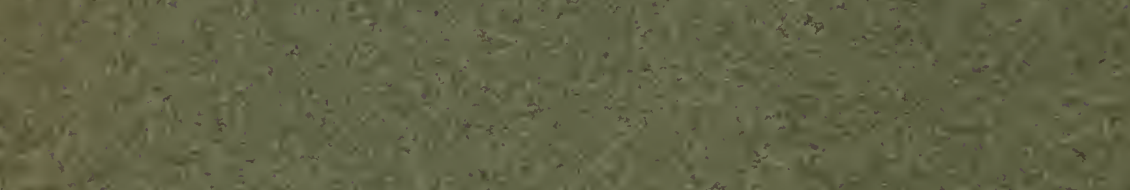
$\lim _{4} x, y, y^{-5}$ $-\frac{1}{1}, 2$

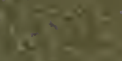

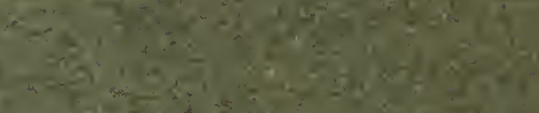
$2 x^{2}$

13.

a

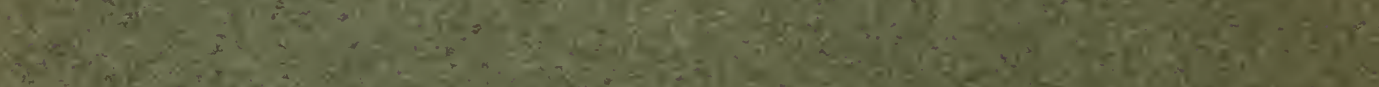

2.

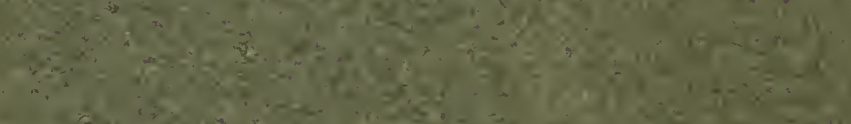

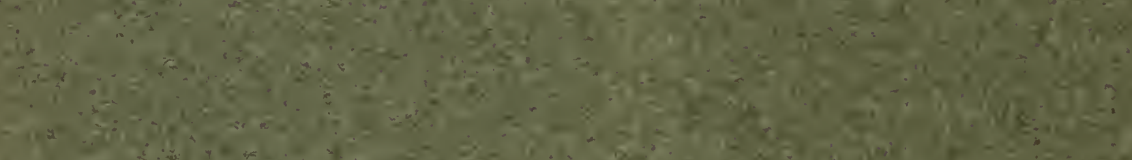

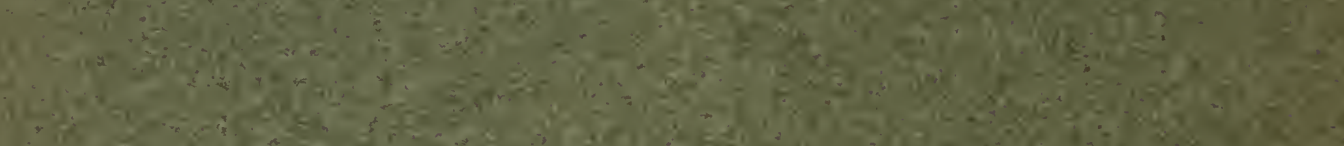

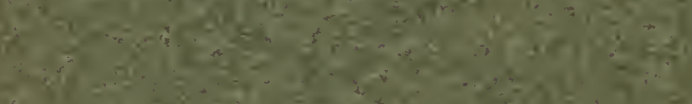

f

f

f

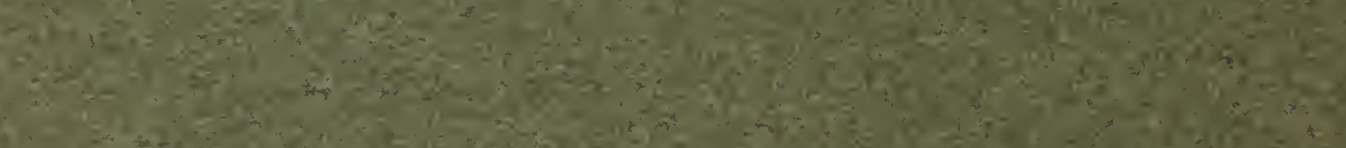

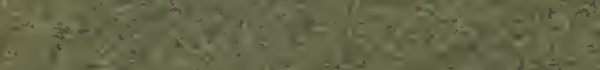

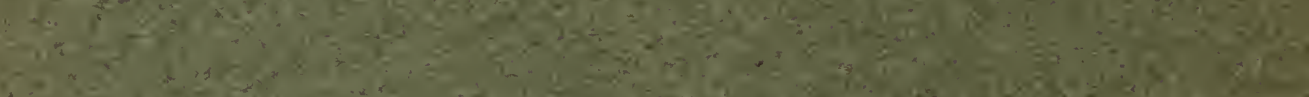

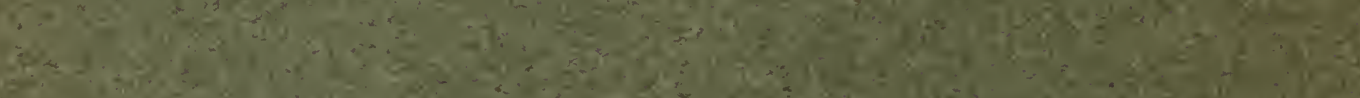

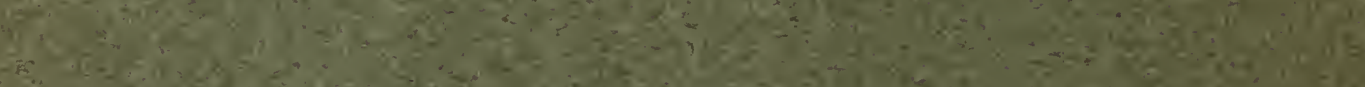

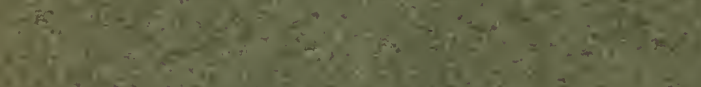

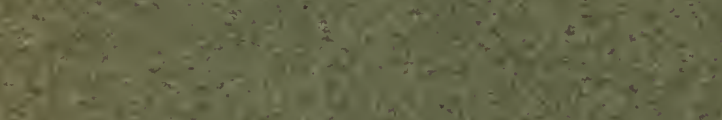

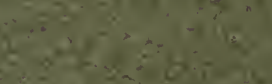

$4=$ 


\section{THE BAHAMA ISLANDS}




\section{THE GEOGRAPHICAL SOCIETY \\ OF BALTIMORE}

\section{THE}

\section{BAHAMA ISLANDS}

EDITED BY

GEORGE BURBANK SHATTUCK, Ph. D.

Associate Professor of Physiographic Geology in the folns Hopkins University

THE JOHNS HOPKINS PRESS

Olew York

THE MACMILLAN COMPANY

LONDON : MACMILLAN \& CO., LTD.

1905

All rights reserved 


\title{
THE GEOGRAPHICAL SOCIETY \\ OF BALTIMORE
}

\section{FISHES OF THE BAHAMA ISLANDS}

\author{
BY \\ BARTON A. BEAN
}

SPECIAL PUBLICATION FROM

THE BAHAMA ISLANDS

BY PERMISSION OF

The Geographical Society of Baltimore

1905 


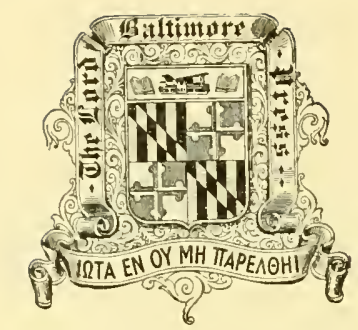

Ebe ffriedenwafo Companp BALTIMORE, MD., U. \&. A. 
FISHES OF THE BAHAMA ISLANDS 



\title{
FISHES OF THE BAHAMA ISLANDS
}

BY

\author{
BARTON A. BEAN, \\ Assistant Curator of the Division of Fishes, U. S. National Museum.
}

\section{INTRODUCTION.}

The Bahama Islands, lying as they do between latitudes $21^{\circ}$ and $28^{\circ}$ north, have a tropical fish fauna, similar to other parts of the West Indies; ninety per cent of the list of one hundred and eighty-three Bahama species here enumerated as collections in the U. S. National Museum and elsewhere, made largely by the Bahama Expedition in 1903, and by the Bureau of Fisheries steamer Albatross in 1886, are credited to the West Indian fauna. Forty per cent of this list have also been found in Bermuda, and seventy per cent along and close to the Florida coast. But eight and one-half per cent of this list have been recorded from the Pacific.

A comparison with the Bermuda fauna shows an exceedingly close relationship between it and the Bahama fauna. Almost all of the fishes known to the waters of Bermuda are found in the waters of the Bahamas. In fact, Bermuda is the northeast end of the West Indian region, which includes the Bahamas.

The fish fauna of the Bahamas is varied, but not so rich as other similar faunas; certain forms are rare, comparatively speaking, and the hauls made with the twenty-fathom seine, twelve feet deep, and of fine mesh, were usually surprisingly light, botl as to number of species and individuals taken. It was only possible to draw the seines on smooth shores, plenty of which were found, but the waters at the time of our visit seemed more or less barren. The fishes on the coral heads were fairly abundant, such forms as Chlorichthys, Iridio, Batistes, etc., being quite common, as were the young tang. The Chcetodonts were rare. Our observations led us to agree with Professor Mayer, who says: "The Bahama region is richer in corals, poorer in fishes and in invertebrates, and far poorer in pelagic life than that of the Tortugas." 
It is quite impossible to gire statistics as to the number and value of the fishes taken in the Bahamas. No record is kept of fishes sold in the markets. Low prices prevail and in the absence of the best grades of beef, mutton and the like, large quantities of fishes are annually consumed. At the time of our visit, June 16 to July 20, 1903, the supply of fish in the wells of the boats in Nassau harbor seemed to be ample and in excess of the demand. The following kinds are esteemed as food: snapper, mutton-fish, groupers, pompano, grunts, jacks, rumners. porgies, angel-fish, pork-fish, hog-fish, tangs, turbot and shell-fish. Those considered of fair quality are: bonito, king-fish, shad (Gerres), goat-fish, mullet, goggle-eve. sqliirrel-fish, hound-fish, flyirg-fish, amber-fish or amber jack, etc.

Of the one hundred and eighty-three species here enmmerated fully fortytwo are of primary importance as food-fishes, while twenty-four may be regarded as of secondary importance. About ten other speeies are sometimes eaten, but little esteemed, and a few are often unfit for human consumption, being poisonous. The Barracuda, though eaten at times, will often cause great discomfort to those partaking of its flesh. In speaking of the morays Catesby sars: "The inhabitants of the Bahama Islands will eat only the green sort, rejecting those which are black as poisonons." He also refers to the unicornfish (Alutera scripta) as being poisonous, and of the rock-fish (Perca marina venenose punctutu) says: "This fish has a worst character for its poisonous quality of any other among the Bahama Tslands."

As will realily be seen by the illustrations (Plates J.II-LXI) from drawings by Mr. A. H. Baldwin, the fishes of the Bahamas are not only useful for food, but also as an attraction to the many risitors to the Islands. Their beanty in life. as they swim to and fro among the sea fans and corals, is indescribable, and one never tires looking through the water bucket with glass bottom. or better still, through the floor of a glass-bottom boat. The "Sea Gardens" of Nassau harbor are famous for their beautr, but they are meager in attraction to some of the bottoms observed farther south. The rock-beauties, angel-fishes, turbot, tang, parrot-fishes, pork-fish, hog-fish, cock-eye pilot, and many others are plainly seen in the clear water and as they flash their beautiful colors fill the observer with wonder and admiration. ${ }^{3}$

${ }^{1}$ The Natural History of Carolina, Florida, and the Bahama Islands, etc., Vol. II, 1743.

${ }^{2}$ Loc. cit.

${ }^{3}$ Popular accounts of the fishes of the Bahamas are to be found in American Fishes, Goode, and in American Food and Game Fishes, Jordan and Evermann. 
For collecting in the Bahamas seines are useful, but they should not be too long nor deep; seventy-five feet long and eight feet deep, with a fine-mesh pocket, wonld probably prove of more service in the shallow waters than longer nets. The Bahama traps are useful, but should be specially constructed of closer woven wire than that used for conmercial purposes. Dip-nets from four to six feet square, held out by spreaders and baited with conch meat, were found most successful in capturing beautiful fishes around the coral heads. These fishes will nibble longer at the bait offered them on hooks without being captured than any we have heretofore seen. The oyster dredge fitted with netting did quite well, but the tangle bars for deep water were lost on the sereral occasions used. This was much to be regretted, as many good things were expected from this sort of fishing.

The meat of the conch is much used as bait. The groupers, grunts and the like are known as bottom fish and are taken by hook and line, while the shad and jacks swim near the surface and are taken in nets. The so-called "passing jack" or "black jack" is said to be one of the best fishes running into Nassau harbor and other places among the Islands. They are taken in large numbers in August and September by means of nets quickly drawn around the schools.

I would express my thanks to Mr. Joseph S. Lewis, of the Johns Hopkins Medical School, and to Mr. J. B. G. Custis, both of whom were assigned to me as assistants in collecting, and to Mr. Randall, who had charge of the launch. To Messrs. Augustus Willige and C. A. McKnew, assistants in the Dirision of Fishes, thanks are due for help rendered in identifying the collections.

\section{ANNOTATED LIST OF BAHAMA FISHES.}

The Bahama Expedition of 1903 collected some highly interesting forms, Stathmonotus, Chriodorus and Terma having heretofore been recorded only from Florida, and the curious goby, Garmannia, indefinitely assigned to the West Indies. So far as the list here given is concerned, I need hardly say that it is rery incomplete as a catalogue of the whole Bahama fish fauna, but I have thought it best to confine myself at this time to the specimens at hand and not give a list from recorded species and supposition as to what may be found in the region under discussion.

The ocean deepens rapidly at many places around the Islands and the deep-sea fauna must be rich. Such forms as Gonostoma, Stomias and Echio- 
stoma have been found in the Bahama Channel, also Pseudoscopelus in the Old Bahama Straits.

\section{Family BRANCHIOSTOMATIDE (Lancelets).}

Astametron luCAYANum Andrews.

This form has been found at Bimini and Nassau. Adult and young were obtained by Dr. Andrews, found swimming at the surface in the evening in June and July, 1892. It was found also in calcareous sand.

Family GINGLYMOSTOMIDE (Nurse Sharks).

Ginglymostoma cirratua Gmelin (Nurse Shark).

Large shark abundant about the coral reefs of the West Indies and on the west coast of Mexico. A female of this species was taken by the Expedition at Green Cay on June 29, 1903. It was 7 feet 9 inches long and contained seventeen egg capsules. Numerous specimens were seen.

Family GALEIDAs (Requiem Sharks).

Hypoprion BREvirostris Poey (Short-nosed Shark).

This shark grows to a length of $y$ feet; it ranges throughout the West Indies and was taken by the steamer Albatross at Watlings Island, March 5, 1886.

Carcharhints obsculius Le Sueur (Dusky Shark).

Middle Atlantic Ocean. Grows to a length of 9 or 10 feet. Numerous examples of what the writer took to be this shark were observed north of Abaco Island. 'They followed the wake of the vessel, often coming to the surface close by, affording a good target for the rifles aboard, but seemed to be little disturbed by the bullets shot at them.

Family SPHYRNIDE (Hammer-headed Sharks).

SPHyRNA TIBURo Linnæus (Shovel-head Shark).

The maximum length of this shark is about 5 feet; it has an exceedingly wide range, occurring from the coast of Long Island, throughout the West Indies, and across the Pacific to China. The steamer Albatross secured specimens north of Abaco in 1886.

Family DASYATIDA (Sting Rays).

Urolophus Jamaicensis Cuvier (Round Sting Ray).

This form occurs throughout the West Indies, and was obtained by the Expedition at Nassau, and at the eastern end of Hog Island. 
Family ALBULIDA (Lady Fishes).

Albula vulpes Linnæus (Lady Fish).

Tropical seas on both coasts of North America, northward in the Atlantic to Cape Cod and in the Pacific to San Diego.

Collected by the Expedition at Spanish Wells, July 4, 1903.

Other common names for this fish are: "banana-fish," "bone-fish" and "macaibi."

Family ELOPIDAS (Tarpons).

Elops saurus Linnæus (Big-eyed Herring).

This rather indifferent food-fish reaches a length of 3 feet or more; it is found in all tropical seas and strays northward to Massachusetts and Lower California.

Collected by the Expedition at the east end of Hog Island, June 18, 1903. The young were abundant.

Family CLUPEIDA (Herrings).

JENKINSIA sTOLIFERA Jordan and Gilbert.

This interesting little fish, heretofore known from the Gulf of Mexico (Key West to Yucatan), was obtained by the Expedition at Spanish Wells, July 4, 1903.

Sardinella sardina (Poey) (Scaled Sardine).

West Indian fauna; abundant. Collected by the steamer Albatross at Nassau.

Sardinglaa clupeora (Cuvier and Valenciennes).

Green Turtle Cay, 1888. C. L. Edwards.

Family SYNODONTIDĖ (Lizard-Fishes).

Synodus INTERMEdus (Agassiz) (Lizard-fish).

A very large specimen was observed by me in Nassau Harbor, but we failed to secure it. It refused all bait offered and the attempts to grapple it with large hooks were unsuccessful. Several small specimens were taken.

The steamer Albatross collected S. intermedius at Watlings Island and Abaco.

Trachinocephalus Myops Forster (Ground Spearing; Lagarto).

Abundantly distributed throughout the West Indies and oceurring northward on Atlantic coast to the Carolinas. Collected by the Expedition at Clarence Harbor, July 15, and off an island near Nassau, July 20, 1903. 
Family MUR.ENESOCIDA.

Stilbiscrs edwarnsi Jordan and Bollman.

Collected at Green Turtle Cay in 1888, by Charles L. Edwards. Described in Proc. U. S. Nat. Mus., Tol. XI, 188s, p. 549.

\section{Family OPHICHTHYID.E (Snake EeIs). \\ Spiagebranchus axgctaormis (Peters).}

Collected by Glover MI. Allen and Thomas Barbour off Abaco, 190t, and referred to in their "Narrative of a trip to the Bahamas," Cambridge. Mas... Dec., 1904 ; privately printed.

\section{Verima kendalli Gilbert.}

A single species belonging to the family Ophichthyida (snake eels), heretofore known only on the coast of Florida, was obtained by the Expedition at Green Cay, June 30, 1903.

\section{Family MURANIDA (Morays).}

Lrcodonts morisga Cuvier (Common Spotted Moray).

This distinctly marked eel reaches a length of 3 feet. It has been found in the West Indies and about Florida, ranging as far southward as Rio Janeiro and St. Helena. In the middle of July, 1903, a specimen was taken by the Expedition at Nassau.

Lycodontis funebis Ranzani (Black Moray).

This eel is the largest of our American species, reaching a length of 6 feet or more and being noted for its extreme ferocity. It is common on both of our coasts, from Florida Keys to Rio Janeiro and Gulf of California to Panama. A specimen was obtained by the steamer Albatross at Nassau during March, 1886.

\section{ECHIDNA CATExata Bloch.}

A form of the most highly specialized morays; small in size but generally common in the West Indies and from Bermuda to Surinam. Collected by the steamer Albatross at Abaco in March, 1886. 
Family MYRIDA (Worm Eels).

MYrophis puxetites liitken.

This species of eel, resembling an earthworm in appearance and size, is found in the West Indies and along the Gulf Coast southward to Surinam. Two specimens were collected by the Expedition off Governors Island, July \%, 190:3. Taken by oyster dredge in j fathoms of water on a bottom of coral sand.

\section{Family P(ECILIID.I: (Killifishes).}

Cyprinodor variegatís Lacépède (Sheepshead Minnow).

This little fish is widely distributerl. being found in brackish waters from Cape Cod to the Rio Grande. Tery abundant in the lake near Cockburu Town, Watlings Island, where specimens were found by the Expedition, July 11, 1903.

Cyprinodon variegatus riverendi, described by Poey from Cuban specimens, has also been recorded from the Florida Keys and obtained by the steamer Albatross at Green Cay, April 12, 18 st.

\section{Gambesia affixis Baird and Girard (Top Minnow).}

This interesting little fish, known to the Cubans as "guajacones," and named Gambusia by Poey after the Cuban word gambusino, meaning nothing, reaches a length of but 2 inches. It is riviparons, the young coming forth in the summer when about one-third of an inch long.

The top minnow is found in marshes and lagoons of the southern and Gulf coasts from Delaware to Mexico, often ascending rivers into fresh water. Collected by the Expedition in lake near Cocklum Town, Watlings Island, July $11,1903$.

Family ExOCoNTID.1: (Flying-fishes).

Exocetes Lineatus Cuvier and Talenciemes (Striped Flying-fish).

Found in the warm seas of the Atlantic, but not abundantly. Specimens have been recorded as taken from Corea, the Madeiras, Canaries and Bermuda. The specimen secured by the Expedition flew aboard the ship at Cat Island during the night of July 8, 1903.

Family HEMIRHAMPHIDA (Half-beak Gars).

\section{Hemirhamputs blisiliexsis Linnæus (Half-beak).}

Grows to a length of 15 inches, is a good food-fish, and is found in more or less abundance from Key West, Florida, southward to Brazil. Obtained by the Expedition at C'larence Harbor, July 14, 1910:3. It seemed to be rare in the Bahamas at the time of our visit. 
Chrodorus atherinotdes Goode and Bean (Hard Head).

This interesting fish, heretofore recorded only from Key West, Florida, was obtained by the Expedition at Spanish Wells, July 4, 1903. A single example, $4 \frac{3}{4}$ inches long.

\section{Family ESOCIDA (Gars).}

Tylosurus notatus Poey (Silver Gar).

This species, known also as "long jaws" and "needle-fish," is common at Key West and throughout the West Indies. It reaches a length of 20 inches. Obtained by the Expedition at Nassau and Spanish Wells during June and July, 1903, being especially abundant at the latter place.

\section{Tylosurus caribbeus Le Suemr (Silver Gar).}

This species inhabits the West Indies. One specimen was obtained by me at Nassau during June, 1903.

\section{Truosurus acus Lacépède (Hound Fish).}

\section{Plate LIII.}

This fish grows to a length of 4 feet and has been recorded from the West Indies, the Bahamas and Bermuda. It occasionally strays northward to the coast of Massachusetts. Taken by the Expedition at Spanish Wells, July 4, and at Clarence Harbor, July 15, 1903.

\section{Family SPHYRANIDA (Barracudas).}

SPHYR ANA PICUdA Bloch and Schneider (Barracuda).

The great Barracuda, Picuda, or Becuna, grows to a length of 6 feet and may well be termed the wolf of the sea. It is eaten but not much esteemed. Very common in the tropics, ranging the high seas throughout the West Indies, from Brazil northward, including Bermuda, to the New England coast. Taken by the Expedition at Spanish Wells, Governors Harbor, Powells Point, Clarence Harbor and Nassau during June and July, 1903.

\section{Family ATHERINIDAi (Silversides).}

Atherina stipes Mïller and Troschel (Friars).

This species includes the A. laticeps of Poey. It is abundant throughout the West Indies, the Gulf of Mexico and the Bahamas. Of small size and only food for other fishes. Taken by the Expedition near Nassau, Spanish Wells, the Current, and Clarence Harbor during June and July, 1903. 
Atherina ARdea Jordan and Gilbert (Slender Friar).

By no means rare, but occurring in less abundance than $A$. stipes. It is found in the Gulf of Mexico, at Key West and Cozumel; specimens also having been collected by the steamer Albatross at Watlings Island, Rum Cay, Cat Island and Abaco during March, 1886.

\section{Family MUGILIDAE (Mullets).}

Mugil Curema Cuvier and Valenciennes (White Mullet).

An important food-fish, running in large schools and ranging on both our coasts from Cape Cod to Brazil and Magdalena Bay to Chili. It grows to a foot in length. Taken by the Expedition at Powells Point, July 8, 1903.

"Blue-back mullet," "Liza" and "Liza Blanca " are names also applied to this fish.

\section{Mugil trichodon Poey (Fan-tailed Mullet).}

A deeper fish than the $M$. curema and having a less extensive range, occurring from Florida Keys to Brazil; abundant at Key West, but rare about Cuba. One specimen was collected by the Expedition at Spanish Wells, July 4, 1903 .

Family HOLOCENTRIDA: (Squirrel-fishes).

Holocentrus ascensionis Osbeck (Squirrel-fish).

This is one of the most brilliantly colored of our tropical fishes. It attains a length of about 2 feet and may be found around the rocks and reefs of the West Indies; ranging from Florida to St. Helena; the Expedition secured a specimen in Nassau harbor, June 23, 1903. It is not very important as a food-fish, but is frequently seen in the tropical markets. Observed in Nassau market.

\section{Holocentrus vexillarius Poey.}

Taken by the steamer Albatross at Abaco, April, 1886.

Holocentrus coruscus Poey (Squirrel-fish).

Recorded from Green Turtle Cay, where it was taken by C. L. Edwards in 1888.

Holocen'trus siccifer Cope.

Described in $\mathbf{1 8 6 6}$ from a specimen taken at New Providence. 
Family SCOMBRID.E (Mackerels).

Gramosarda alleterata (Rafinesque) (Bonito).

This fish, known in the Mediterranean as "Tumny," is common throughout the West Indies and ranges northward to Cape Cod. It is a good food-fish. An example was obtained by the Expedition on a trolling line, between Andros Island and Green Cay, on Jume 28, 1903.

Scomberomores cavalua Cuvier and Talenciennes (King-fish or Cero).

This large fish is common in the West Indian region. It attains a length of 5 feet or more and is used as food. Observed in the Nassau market.

\section{Family CAR.ANGIDAE (Pompanos).}

Caranx bartholomer Cuvier and Talenciemnes (Yellow Jack).

An indifferent food-fish, occurring in the West Indies and frequently straying northwards as far as the Carolinas. It was taken in April, 1886, by the steamer Albatioss at Nassan.

\section{Caraxt Crisos Mitchill (Jack).}

Unlike C.bartholomei Cuv. and Valen., this fish has gained rather a prominent name among the food-fishes, more especially in the West Indies, where it occurs in abundance. Its range is also greater, covering the western Atlantic from Cape Cod to Brazil. Its qualities as a game fish have made it a farorite with many sportsmen. "Crévalle," "runner," "jurel" and "yellow mackerel " are other names applied to this fish. Several specimens were secured at Nassau by the steamer Albatross in April, 1886.

\section{Carant latus Agassiz (Horse-eye Jack).}

This species of Caranx is found on the west coast of Mexico, in the West Indies, and ofttimes as far north as Virginia. It is generally regarded as poisonous and cansing the disease known as Cignatera if eaten. A specimen was taken by the Expedition near Cape Hatteras in June, 1903, several more being secured at Spanish Wells and Clarence Harbor in July, 1903.

\section{Carant reber Bloch (Carbonero).}

Found only in the West Indies heretofore; a single specimen was secured at Nassau in June, 1903. by the Expedition. It is much less abundant than the other Caranx mentioned ahove, and for this reason has no value as a foodfish. 
Trachurops crumenophthamus Bloch (Goggle-eye).

Also known as "big-eyed sead," "goggle-eye Jack" and "chicharro." It occurs thronghont the West Indies northward to Cape Cod, and in the Pacific on the west coast of Mexico. In the Hawaiian Islands it is esteemed as a food-fish, being found in great abundance and called "akule" by the natives. An abundant fish in the Nassan market at the time of our visits in June and July, 1903. A fairly good fish and one of the lowest priced. The usual length of market specimens was 8 or 9 inches.

Trachinotes ellcatus Linneus (Round Pompano).

This well-known food-fish exceeds a foot in length and is found in the West Indies; it ranges from Cape Cod to Brazil, being common sonthward and occasionally found northward in the Gulf Stream as far as Woods Holl. Collected by the Expedition at Tarpum Bay and east end of Hog Island in July, 1903.

\section{Trachinotus glaucus Bloch (Old Wife).}

A handsome fish, unimportant as food, found among the West Indies and along the coast from Virginia southward to the Caribbean Sea. In size it rarely exceeds a foot. Several specimens were obtained by the Expedition at Nassau, June 20, 1903.

Trachinotus goodei Jordan and Evermann (Great Pompano).

Also commonly called the "permit;" a good food-fish, though not as highly valued as $T$.carolinus. It often grows to a length of 3 feet, specimens of this size weighing about thirty pounds, being the largest size attained by any of the pompanos. It occurs in the West Indies, northward to Florida. Collected by the Expedition at Hog Island, June 18, 1903.

Decapterus macareluus Cuvier and Valenciennes (Mackerel Scad).

Found in the warmer parts of the Atlantic, straying northward to Cape Cod. Of no value as food. Two specimens were taken by the Expedition near the edge of the Gulf Stream off Cape Hatteras, Jmne 6, 1903.

Seriola rivoliana Cuvier and Talenciennes (Amber-fish).

As a food-fish this species is unimportant, comparing unfavorably in this respect with the majority of the species in this genus. It is of wide distribution, ranging from the Mediterranean to Brazil, throughout the West Indies and occasionally on the coasts of Florida and Sonth Carolina. A specimen was obtained by the steamer Albatross, March 5, 1886 . 
Large examples of $S$. rivoliana were observed in Nassau Harbor. Two brought to the schooner's side by hand-line fishermen weighed about 50 lbs. each.

\section{Naucrates ductor Linnæus (Pilot-fish).}

A fish of wide distribution, inhabiting the open seas, being found occasionally on the Atlantic coast from Cape Cod to the West Indies. Two specimens were taken by the Expedition, the one from the edge of Gulf Stream, the other at N. Lat. $31^{\circ} 13^{\prime}, \mathrm{W}$. Long. $74^{\circ} 41^{\prime}$, in June, 1903.

\section{AleCtis CILIARIS (Bloch) (Thread-fish).}

Both coasts of tropical America; common around the Florida Keys. Obtained at Green Turtle Cay, 1888, by C. L. Edwards.

\section{SELENE VOMER Linnæus (Horsehead).}

One of the handsomest and commonest of the Moon-fishes, deriving its name of Horsehead and also that of Lookdown from the peculiar shape of its head. Its flesh is excellent, being generally considered a great delicacy. Found on both coasts, from Cape Cod to Brazil, Lower California to Peru; more common about the sandy coasts of tropical America. A specimen was taken by the Expedition at Nassau, June 20, 1903.

\section{Family NOMEIDA.}

Psenes cyanophrys Cuvier and Valenciennes.

A small fish occurring in the Atlantic, Pacific and Indian oceans, being widely distributed in the warm ocean currents. Secured by the Expedition at Green Cay, June 29, 1903.

Nomeus Gronovir Gmelin (Portuguese Man-of-war Fish).

This fish derives its name from its habit of seeking protection beneath the jelly-fish known as the Portuguese man-of-war, moving freely about its poisoned tentacles. The single example obtained by the Expedition was taken with its host in the open ocean southeast of Cape Hatteras in June, 1903.

\section{Family BRAMIDA (Pomfrets). \\ Brama RaII Bloch (Pomfret).}

Found in the open seas at considerable depths; rarely in the Atlantic, more frequently on the Pacific coast from California north to Puget Sound. 
A young specimen was taken near Cape Hatteras, June 15, 1903, by the Expedition. This fish attains a length of 2 to 4 feet. On the Pacific coast it is highly valued as a food-fish.

\section{Family CHEILODIPTERIDE (The King of the Mullets).}

\section{Apogon prgmentarius (Poey).}

An interesting little fish heretofore recorded from Cuba. One specimen was obtained by the Expedition at Golding Key, Andros Island, June 26, 1903. Color in life red; in alcohol whitish, profusely covered with small black spots.

\section{Apogonichthrs stellatus Cope.}

Two specimens of this rare species were obtained by the Expedition at Golding Key, Andros Island, June 27, 1903. They were of a uniform black color when captured, but since being in alcohol have faded to a reddish-brown with more or less metallic luster, thickly dotted with small dark spots and numerous star-shaped blotches each with a silvery center.

Professor Cope described the species from a specimen (the only one known) said to have come from Nassau. Our specimens are 2 and $2 \frac{1}{4}$ inches long.

\section{Family SERRANIDA (The Sea Basses).}

Epinephelus maculosus Cuvier and Valenciennes (Red Hind).

\section{Plate LVII.}

This is one of the smallest of the Groupers. Like all the others it is highly esteemed as food and for its game qualities. It ranges from Carolina to Brazil, being rare on our coast but more frequent in the West Indies and the Bermudas. Several specimens were collected by the Expedition at Nassau during June and July, 1903. It attains a length of about 2 feet.

Epinephelus mystacinus Poey (Cherna de lo Alto).

Found in the deeper waters of the West Indies, southward to Brazil; reaching an approximate length of 2 feet. A good food-fish, but not found in such quantities as to make it of commercial value. Collected by the Expedition at Nassau, June 22, 1903.

\section{Epinephelus striates Bloch (Nassau Grouper).}

This is one of the best marked and most important food-fish of its kind. Found throughout the Bahamas and in the West Indies, northward to Florida. 
It often reaches a length of three feet and a weight of about fifty pounds, this being the largest size attained by any of the species of this genus. A fifteenpound specimen was taken by the Expedition in Clarence Harbor, and the fish was fairly common in the wells of the fishing boats in Nassau harbor in June, 1903. It is also one of the commonest of the food-fishes of Bermuda. The younger forms are known as "Hamlet grouper."

\section{Mrcteroperca venexosa APUa (Bloch).}

West Indies; Florida Keys to Brazil. C. L. Edwards collection, Green Turtle Cay, $18 s 8$.

\section{Petrometopon cruentatus (Lacépède) (Coney or Red Itind).}

This is a handsome fish, reaching a length of 1 foot and inhabiting the waters of the West Indian region generally. It is a fair food-fish. Specimens were obtained by the Expedition at Nassan and Rum Cay in June and July, 1903.

\section{Bodianus fultes (Linnæus) (Yellow Fish).}

This species grows to a length of 1 foot, is a fairly good food-fish, and occurs from Bermuda to Florida and thronghout the West Indies. "Niggerfish," "butter-fish," "guativere" and "guativere amarilla" are other names applied to the species. One example collected by the Expedition at Watlings Island, July 11, 1903.

Bodinus fulves fuber (Bloch and Schneider) (Red Guativere).

A variety of the preceding, and like it variable in color. Of the same general range. Olotained by the Expedition in Nassau, July 20, 1903.

\section{Bodianus fulus puxctatus (Limmeus) (Negro Fish).}

\section{Plate LVIII.}

An old and well-known but rather unimportant food-fish of the Bahamas, Bermuda and the West Indies generally. Dr. Goode in his list of fishes observed and collected in Bermuda during the months of February and March, 1872, says: "The names 'butter-fish' and 'nigger-fish' are in use also at Barbados, St. Thomas and the Bahamas, as applied to this and an allied species. The first refers to the color and soft, oily feeling of the yellow variety; the latter probably also to color."

\footnotetext{
${ }^{4}$ Bulletin V, of the U. S. National Museum, Washington, D. C., 1876.
} 
Specimens were obtained by the Expedition at Nassan and Clarence Harbor in June and July, 1903.

\section{Family RHYPTICIDA (Soap Fishes).}

Ruyptices bistrisinoses (Mitchill) (Soap Fish).

\section{Plate LII.}

A curions fish, named on account of the soapy or oily feeling of the smooth shin. Found along the south Atlantic coast of the United States from Charleston to Pensacola, straying northward to coast of New England. Obtained by the Expedition at Nassan and Green Cay in June and July, 1903.

\section{Family KYPHOSID.E (Sea Chubs).}

Kirphosus sectatrix (Linnæus) (Bermuda Chub).

The "rudder-fish," "chub," or " chopa blanca," as it is rariously ealled, oceurs in the open ocean from the West Indies northwarl to Cape Cod, and eastward to the Canary Islands. It is observed following ressels, probably for the food thrown overboard, and is often seen around the rudder, from which habit is derived one of its common names.

Obtained by the Expedition at X. Lat. $31^{\circ} 13^{\prime}, \mathrm{W}$. Lon. $14^{\circ}$, on June $13,1903$.

\section{Family HAMULONIDA: (Grunts).}

\section{Bathystona aurolineatum (Cuvier and Valenciennes) (Jenignano).}

One of the smaller species of grnnts, occurring thronghout the West Indies. Obtained by steamer Albatross at Abaco Island, April, 1886.

BathYstoma rimator (Jordan and swain) (Tom Tate or Red-mouthed (rimt).

This grunt occurs in the Atlantic from Cape Hatteras to Trinidad. It is one of the most abmulant of the food-fishes about Charleston Harbor. Obtained by the Expedition at Clarence Harbor, July 14, 1903.

\section{Hamulon albur Cuvier and Valenciennes (Margate Fish).}

This is one of the most important and highly esteemed food-fishes of the West Indies, the Florida Keys, the Bahamas and Bermuda. It grows to a length of 2 feet, and is more or less abundant. Numerous specimens were observed and captured by the Experlition in the varions places visited, and the fish was always a weleome addition to the mess. 


\section{Hemulon Carbonarium Poey (Ronco Carbonero).}

A smaller species than the H. album, seldom exceeding 10 inches in length, but having some value as a food-fish, especially around Cuba, where it is found in abundance. It occurs in much smaller quantities in the rest of the West Indies, the Bermudas and Brazil. Several specimens were secured at Nassau by the steamer Albatross in April, 1886.

\section{Hamulon flavolineatum (Desmarest) (Open-mouthed Grunt).}

This is an exceedingly well-marked species, reaching a foot in length and being regarded as a good food-fish. It is common throughout the West Indies; ranges from Florida Keys south to Brazil, being found in greatest quantities about Porto Rico. Specimens were obtained at Nassau market and Abaco by the steamer Albatross in March, 1886. Other names by which this species is known are "French grunt" and "ronco condenado."

\section{Hæmulon melanurum (Linnæus) (Black-tail Grunt).}

This grunt is a good food-fish. It reaches a length of 1 foot and is common to the West Indies. Collected by me in the Nassau market, June, 1903.

\section{Hæmulor plumieri (Lacépède) (Common Grunt).}

This is one of the most abundant and highly prized of the smaller varieties of food-fishes found throughout the West Indies, Florida Keys, Bahama Islands and other nearby localities. It grows to a length of 1 foot or more, but the average size of those found in the markets is much less. Obtained by the Expedition at Nassau in June, 1903.

\section{Hæmulon sciurus (Shaw) (Yellow Grunt).}

A handsome grunt, also known as "squirrel grunt." It grows to a length of 18 inches, but found in the markets much smaller. Found throughout the West Indies, Florida Keys, Bahamas and Bermuda.

Brachygenys Chrysargrreus (Günther) (Small-mouthed Grunt).

A little fish reaching but 6 inches in length. Common at Key West and Havana. The steamer Albatross obtained it at Abaco in 1886.

\section{Anisotremus virginicus (Linnæus) (Pork-fish). Plate LIV.}

A very good food-fish, known also as "sisi," reaching a length of 1 foot and ranging from Florida to Brazil; found frequently in the West Indies. 
Secured by the Expedition at Nassau, July 2, 1903. Named for the Virgin Islands, where the fish is common. and not for Virginia, where it is seldom if ever found.

\section{Family LUT.JANIDA: (Snappers).}

LutJanus analis (Cuvier and Valenciennes) (Mutton Fish).

A large, handsome food-fish, often sold as red snapper, occurring on the fishing banks of the West Indian waters, Florida and the Bahamas. Obtained at Nassau by the steamer Albatross. Observed in the markets at the time of our visit.

Catesby says: "For the excellence of its taste it is in greater esteem than any other at the Bahama Islands."

\section{LutJanus Apodus (Walbaum) (Schoolmaster).}

Grows to a-weight of 8 pounds. An attractive fish, used for food. Common to Bahama, Florida and the West Indies generally.

Lutjandos Buccanella (Cuvier and Valenciennes) (Black-finned Snapper).

Occurring in the West Indies; taken in deep water. Obtained by the steamer Albatross at Nassau in 1886.

\section{LutJanus Griseus (Linnæus) (Gray Snapper).}

This is one of the commonest and best food-fishes of the West Indian fauna. It is known as "mangrove snapper," attains a length of three feet (18 lbs.), and is found in the Bahamas, Bermuda, Florida and the West Indies.

\section{Lutjands mamogoni (Cuvier and Valenciennes) (Mahogoni Snapper).}

One of the smaller species of snapper, found in the West Indies, etc. Observed and collected by the Expedition in Nassau market during June and July, 1903.

\section{LutJanus synagris (Linnieus) (Red-tailed Snapper).}

One of the most abundant of the snappers, rarely exceeding a foot in length, chiefly inhabiting shallow waters. A food-fish of importance about Havana, occurring there in great numbers, but a little less abundantly found from Tampa to Brazil. Specimens were obtained by the exposition at Nas. sau, July 20, 1903. 


\section{Ocyurus chrisures (Bloch) (Yellow-tailed Snapper).}

A delicious and abundant food-fish ranging from southern Florida to Brazil, and throughout the West Indies. It grows to a length of 2 feet and possesses some merit as a game-fish. The steamer Albatross collected sereral specimens in April, 1886. Observed and collected by the Expedition in Nassau market during June and July, 1903.

\section{Apsilus dextatus Guichenot (Arnillo).}

This is a handsome fish reaching a foot in length and having some value as food. It is found in the West Indies, being rather common about Cuba. A specimen was taken by the Expedition at Powells Point, Eleuthera, July 8. 1903.

\section{Family SPARIDA (Porgies).}

Diplodus argenteus (Cuvier and Talenciennes) (Silvery Sargo).

Found in the West Indies and along the coast from Florida and the Bermudas sonthward to Argentina. One specimen was secured by the Expedition at Nassau, June 20, 1903.

\section{Calames calames (Curier and Valenciennes) (Saucer-eye Porgy).}

This fish reaches a length of 1 foot and besides being excellent eating, furnishes some sport in its capture, being considered a rather good game-fish by many. It is found throughout the West Indies and northward among the Florida Keys. The steamer Albatross collected sereral specimens at Nassau in April, 1886.

\section{Calajius leucosteds Jordan and Gilbert (White-boned Porgy).}

A good food-fish reaching a length of 1 foot and obtained heretofore only at the markets of Charleston, S. C. It was secured by the steamer Albatross at the Nassau market in April, 1886.

\section{Calanus Penva (Curier and Valenciennes) (Sheepshead Porgy).}

Like the rest of the species this is ralued as food. It is very common from southern Florida to Brazil and is known also in the West Indies. A specimen was obtained by the steamer Albatross at the Nassau market in April, 1886. 
Calames bajoxado (Bloch and Schneider) (Jolt-head Porgy).

This is the largest of the porgies, reaching a size of 2 feet and a weight of ten pounds. It is also the most abundant species of this genus and the most important as a food-fish. Found in abundance throughout the West Indies and nortl to the Florida Keys. Taken by the Expedition at Nassau, June 22, 1903.

Family GERRIDA: (Silver Jennies).

Gerres brasiliands (Cuvier and Talenciennes) (Patao).

Found from Cuba to Brazil, and ranking as a good food-fish wherever it is abundant. It reaches a foot in length and is generally common. Collected by the Expedition at Nassau, June 18, 1903.

\section{Gerres cinerecs (Talbamm) (Broad Shad).}

This is one of the largest members of the family Gerrida, reaching a length of more than a foot, and has considerable value as a food-fish. It is common to both coasts of tropical America, north to Florida and to Lower California. Obtained by seines and other nets. Common in the market at Nassan. Obtained by the Expedition at Spanish Wells and Clarence Harbor during July, 1903.

\section{Eucinostomes gula (Cuvier and Valenciennes) (Silver Jenny).}

This is a common species from the coasts of Carolina to Brazil. It grows to a length of six inches and is chiefly valuable as bait. Obtained by the Expedition at Spanish Wells, Watlings Island and Clarence Harbor, during July, 1903.

Eucinostomus Lefroyi Goode (Long-boned Shad).

A bait fish, reaching a length of 8 inches. Common from Bermuda westward to Florida, and sonthward throughout the West Indies. Taken by the Expedition at Spanish Wells, the Current, and Clarence Harbor during July, 1903.

\section{Family PRIACANTHIDE (Catalufas).}

\section{Priacanthus cruentates (Lacépède) (Big-eye).}

This fish is known in Harana as the "catalufa," and is a common food-fish in that market. It is found throughout the West Indies, ranging across the Atlantic to St. Helena and the Canaries. Obtained by the steamer Albatross at Rum Cay. 
Priacanthus arenatus Cuvier and Valenciennes (Catalufa).

Tropical Atlantic, straying northward in the Gulf Stream. Obtained by the steamer Albatross at Nassau.

Family MULLIDAE (Surinullets).

Upeneus maculatus (Bloch) (Goat Fish).

A very handsome, strikingly colored fish, abundant and valued as food. It occurs in the West Indies, and probably in Bermuda. Common in the Nassau market. Obtained by the Expedition at East End of Hog Island (Nassau harbor), along Eleuthera Island and at Clarence Harbor, where many young were seined during July, 1903.

Upeneus martinicus Cuvier and Valenciennes (Yellow Goat Fish).

This species grows to a length of one foot and is valued as food. It is found throughout the West Indies and north to Florida. The steamer Albatross collected it at Nassau in 1886 .

Family CHA:TODONTID舟 (Butterfly Fishes).

Holacanthus tricolor (Bloch) (Rock Beauty).

Plate LXI.

This striking fish inhabits the West Indies, and has been recorded from Bermuda. Numerous specimens were observed in the "Sea Gardens," near Nassau, during June, 1903, but none were taken.

Pomacanthus arcuatus (Linnæus) (Black Angel Fish).

Length one and one-half to two feet. A handsome fish, but little valued as food. West Indies generally, occasionally straying northward to the middle Atlantic coast. Obtained by the Expedition at Nassau and Andros Island during June, 1903.

\section{Chatodon ocellatus Bloch (Spanish Angel Fish).}

West Indian fauna, straying northward. Observed among the coral heads in Nassau harbor. One of the beautiful fishes of the tropics. Obtained by the Expedition at Nassau during June, 1903.

Chatodon Capistratus Linnæus (French Angel Fish).

A beautiful tropical fish, of small size, abundant around the coral reefs of the West Indies. The Chotodonts are the butterflies of the warm seas. Obtained by the Expedition at Nassau, June 19, 1903. 
Angelichthys ciliaris (Linnæus) (Yellow Angel Fish).

One of the most beautiful of fishes, growing to a length of 18 inches. In his catalogue of Bermuda fishes Dr. Goode says: "The angel fish attains a weight of four pounds and as far surpasses all the other fishes of the region in its delicious flaror as in its lovely hues." It ranges throngh the West Indies. Common in the Nassau market and at other places in the Bahamas.

\section{Family TEUTHIDIDAE (Surgeon Fishes).}

Teuthis bamianus (Bloch and Schneider) (Ocean Tang).

This is the most important of the surgeon fishes on account of its large size (reaching a length of 1 foot), and its value as a food-fish. It is found in the West Indies and along the Atlantic coast from Key West to Bahia. Collected by the Expedition at Nassau during June and July, 1903.

Teuthis cæeruleus (Bloch and Schneider) (Blue Surgeon or Tang).

Plate LVI.

One of the commonest of the tangs in the West Indies, reaching a length of eight or ten inches and being used as food. Found also in the Bermudas and ranging from Key West to Bahia. Specimens were obtained by the Expedition at Nassau, Clarence Harbor and the east end of Hog Island during June and July, 1903.

\section{Truthis hepatus Linnæus (Common Tang).}

This is the most abundant of the tangs, common in the West Indies and northward to Florida. Found occasionally as far north as Charleston and southward to Brazil. Several specimens collected by the Expedition at Clarence Harbor, July, 1903.

\section{Family POMACENTRIDAE (Demoiselles).}

Eupomacentrus Leucostictús (Müller and Troschel) (Black Pilot).

An extremely handsome fish, attaining an approximate length of four or five inches and found in large numbers throughout the West Indies north to the western coast of Florida. Collected in July, 1903, at Clarence Harbor, Powells Point and the east end of Hog Island by the Expedition.

Eupomacentrus fuscus (Cuvier and Valenciennes) (Maria Molle).

Found in the West Indies and among the coral reefs at Key West, ranging southward to the Brazilian coast, occurring in abundance almost throughout its entire range. Taken by the Expedition at Nassau, June 24, 1903. 
Erponacentrus adustus (Troschel).

Attaining a length of three or four inches and occurring commonly about Cuba. Collected by the steamer Albatross at Nassau, April, 1886.

\section{Glyphisodon saxatilis (Linneus) (Cow-pilot or Pintano).}

A widely-distributed fish, occurring on both coasts of tropical America, ranging from Florida to Uruguay and Gnaymas to Peru. It reaches a length of six inches and is abundant about the rocks and coral reefs at every point. Specimens were obtained by the Expedition at Nassan and Green Cay, July, 1903.

\section{Family LABRIDA (Wrasses).}

Lacholatius maximus (Walbaum) (Hog Fish).

This is a common and attractive food-fish occurring throughout the West Indies and Bermudas, and ranging north to Key West. It attains a length of 3 feet and a weight of twenty pounds and is generally found in abundance abont the coral reefs. A specimen was taken by the Expedition at Nassau during June and July, 1903, where it was common in the market.

Harpe rufa (Linnæus) (Spanish Lady Fish).

A very attractive fish reaching a length of 2 feet. Found abundantly in the West Indies and ranging from Key West to Rio Janeiro. Obtained by the steamer Albatross in the market at Nassau.

\section{Novaculichthys infirius (Bean) (Flexible Razor Fish).}

Known heretofore only from Cozumel, Yucatan, but obtained by the steamer Albatross at Nassau, April, 1886.

\section{Xrrichtiris psittacus (Linnæus) (Razor Fish).}

A brilliantly colored fish found in the West Indies and from Charleston and Pensacola southward to Bahia. It reaches a length of 15 inches and is rather common. Obtained by the steamer dlbatross at the Nassau market in April, 1886.

\section{Iridio BivitTatus (Bloch) (Slippery Dick).}

This is the smallest species of this genus, the average length being about 6 or $y$ inches. It has an extensive range, occurring throughout the West Indies, and from North Carolina to Brazil, being exceedingly common everywhere among the rocks and reefs. A number of specimens were obtained by 
the Expedition at Spanish Wells, Elenthera Island, Clarence Harbor, and the east end of Hog Island during Jume and July, 1903.

\section{Iridio Garnoti (Cuvier and Valenciennes).}

Reaches a length of 8 or 9 inches and is found in the West Indies. Obtained by the Expedition at Clarence Harbor, July 1\%, 1903.

\section{Iridio macultinisa (Mïller and Troschel).}

Found in the West Indies and ranging northward as far as Beaufort, N. C. Taken by the steamer Albatross at Nassan, April, 1886.

\section{Iridio radiatus (Limnæus) (Pudding-wife).}

Attains a length of 18 inches and ranks as the largest of the American species of Iridio. It is found abundantly in the West Indies and the Bermudas, ranging from Brazil to the Florida Keys. Several specimens were secured in the market at Nassan by the steamer Albatross, April 23, 1886.

\section{Chlorichthys bifasciatus (Bloch).}

A rather common fish found scattered thronghout the West Indies. A number were collected by the Expedition at Clarence Harbor, July, 1903.

\section{Chlonichthys Nitidus (Günther).}

A fish reaching a length of 3 inches and being found in the West Indies. Taken by the Expedition from the Current, Elenthera Island, and at Nassau and Clarence Harbor, during June and July, 1903.

\section{Family SCARIDA: (Parrot Fishes).}

Sparisoma aurofrenatul (Cur. and Tal.) (Gold-bridled Parrot Fish).

\section{Plate III.}

This is one of the most attractive of the parrot fishes, being well marked and highly colored, but like the other species of this genus has no great value as food. It reaches a length of $S$ or 10 inches and is rather common throughout the West Indies. Collected by the Expedition at Nassau, June $24,1903$.

\section{Sparisolia viride (Bonnaterre) (Dark-green Parrot Fish).}

Found in the West Indies and is generally common. It is one of the largest of the species, attaining a length of 2 feet, and is considered a foodfish at Porto Rico. A specimen was secured by the steamer Albatross in the market at Nassau, March, 1886 . 
Sparisoma distinctum (Poey) (Streaked Parrot Fish).

This species ranges throughout the West Indies, and was obtained by the Expedition in the Bahamas during June and July, 1903.

\section{Sparisoma flavescexs (Bloch and Schneider) (Mud Parrot).}

One of the smaller of the parrot fishes, rarely exceeding a foot in length; plain in color; common from Key West to Rio Janeiro. Obtained by the Expedition in the Nassau market, June, 1903.

\section{Sparisoma hoplomystax (Cope).}

Occurs in the West Indies and from Key West to Bahia. It is very common throughout its whole range, being seined in large quantities by the Expedition at Clarence Harbor. A number of specimens were also obtained at Spanish Wells and the east end of Hog Island during July, 1903.

\section{SPARISOMA LORITo Jordan and Swain (Loro).}

Found in the West Indies and used as food by the Porto Ricans. It was collected by the Expedition at Nassau in June, 1903.

\section{Scarus CAruleus (Bloch) (Blue Parrot Fish).}

Widely and abundantly distributed throughout the West Indies northward as far as Chesapeake Bay. It reaches a length of 2 or 3 feet and a weight of twenty pounds, its large size making it the most important of the parrot fishes, although it is not highly valued as food. A specimen was taken opposite Mangrove Cay by the Expedition, June 27, 1903. Common.

\section{Scarus Croicensis (Bloch) (Bullon).}

One of the smaller of the species, its length rarely exceeding 6 or $y$ inches. It is very common throughout the West Indies and ranges north to Key West. Large numbers were obtained at Spanish Wells, Powells Point and Clarence Harbor by the Expedition during July, 1903.

\section{Scarus taniopterus Desmarest (Ribbon-finned Parrot Fish).}

Occurs in the West Indies and is rather numerous. It reaches a length of about 10 inches. Collected by the Expedition in the Bahamas during June and July, 1903. 
Cryptotonus retractus (Poey).

Found in the West Indies and north to Pensacola. Several specimens obtained by the Expedition from the Current, Elenthera, and at Clarence Harbor during July, 1903.

Family ZEIDA: (John Dories).

ZeNion hololepis (Goode and Bean).

Taken by the steamer Albatross off coast of Yucatan and on Little Bahama Bank. Described and figured by Goode and Bean in Oceanic Ichthyology, 1896.

Family SCORPANIDA (Rock Fishes).

SCORPANA PLUMIIERI Bloch (Rascacio).

A handsome but valueless species, more or less common to the south Atlantic coast of the United States, the West Indies, and recorded from Bermuda. The steamer Albatross obtained it at Nassau. At Key West this fish is called "poison toad."

Scorpera brasiliensis Cuvier and Valenciennes (Scorpion Fish).

Found from Charleston to Rio Janeiro. One specimen taken by the Expedition at the Current, July 5, 1903.

Scorperna grandicornis Cuvier and Talenciennes (Lion Fish).

A strikingly handsome fish occurring around the Florida Keys and southward throughout the West Indies to Brazil. The steamer Albatross obtained it at Abaco, April, 1886.

The fishes of this genus are known at Key West as "poison toads" on account of the painful wounds they inflict with their spines.

Family CEPHALACANTHIDA (Flying Gurnards).

Cephalacanthus volitans (Linnæus) (Flying Gurnard).

Plate LX.

A beautifully colored species, of odd form, known in some of the West Indian islands as bat-fish. Found on both coasts of the Atlantic Ocean, ranging north to Newfoundland and south to Rio Janeiro. Recorded from Woods Holl, Massachusetts, Bermuda, Key West and various West Indian islands. Obtained by the Expedition at Nassau during June, 1903. The color sketch by Mr. Baldwin gives one a good idea of the appearance of the fish in life and especially of its handsome pectoral fins. To show this fin to advantage the 
artist took the liberty to draw it down in an mnnatural position; the eye as shown in the picture is rather too small.

Family MALACANTHID.E (Blanquillos).

Malacantues plumeri (Bloch) (Sand Fish).

This species grows to a length of 15 inches or more; it is rather common in the West Indies and used as food. Obtained by the Expedition at Green Cay and Clarence Harbor during July, 1903.

Family DACTYLOSCOPIDA: (Little Star-gazers).

Dactrloscopus tridigitatus Gill (Fingered Star-gazer).

This interesting little fish is found in the West Indies and north to Key West and the Bahamas. Two specimens were obtained by the Expedition at the Current, July 5, 1903.

\section{Family GOBIIDA: (Gobies).}

Gobius glaucofrenum (Gill) (Bridled Goby).

Heretofore recorded from the Florida Keys. Twenty-five specimens were obtained by the Expedition in the oyster dredge off Governors Harbor, Eleuthera Island, July $\%$, 1903, in five fathoms of water.

Gobits soporitor ('mrier and Valenciennes (Sleeper or Caiman Goby).

This species is generally abmdant in tropical seas of both Atlantic and Pacific oceans. Fonnd in the shallow waters of shores and ditches, hiding under stones. Specimens were obtained by the Expedition at salt Key, near Nassan, and at Powells Point, Eleuthera, during June and July, 1903.

Garmaxia hemigrima (Eigenmam and Eigenmann) (Italf-naked Goby).

This highly interesting goby, heretofore indefinitely ascribed to the West Indies, was taken by the Expedition in an oyster dredge on the north side of Green Cay, in about five fathoms of water, June 30, 1903, fire examples, measuring from five-eighths to seren-eighths of an inch in length, being captured.

Family GOBIESOCIDE (Clinging Gobies).

Gobiesox cephalus Lacépède (Cling Fish).

Obtained by the Expedition at Green Cay, in the oyster dredge, in five fathoms of water. 
Goblesox hemes Jordan and Bollman.

Collection of C. L. Edwards, Green Turtle Cay, 18ss. The single speeimen taken was described in Proe. U. S. Nat. Museum, XI, 1888, p. 552.

Family ECHENIID X: (Remoras).

Echeneis raucrateordes Zuiew (Sucking Fish).

This interesting fish ranges from the coast of Massachusetts to the West Indies, being common southward. It is also found in the waters of Bermuda, usually attached to sharks. Obtained by the Expedition at Gregory 'Town, Eleuthera, July, 1903, where they were first noticed by the side of the ressel eating oftal. Numerous examples, eaptured by hook and line.

\section{Family BLENNIIDA (Blennies).}

Labrisomes xuchipixis (Qroy and Gaimard) (Molly Miller).

Common in rock pools of the West Indics. The steamer Albatross obtained this species at Abaco, New Providence and Watlings Island during March and April, 1886. Recorded from Bermuda.

Malacoctexts moorei Eremann and Marsh (Combed Blemny).

This speeies was described in 1899 from a specimen obtained in Porto Rico. It has since been collected in the Tortugas Arehipelago by Dr. J. C. Thompson, U. S. N., at Key West by Bean and King, and obtainer by the Bahama Expedition at Powells Point and Clarence Harbor during July, 1903.

\section{Malacoctexts varius (Poey) (Variegated Blemny).}

An interesting little fish recorded by Poey from Cuba, and obtained by the steamer Albatross at Nassau, Mareh, 1886.

Malacoctenes legubris (Poey) (Dismal Blenny).

Described from Cuban specimens; obtained by the steamer Albatross at Nassau, March, 1886.

Malacoctencs ocellates (Steindachner) (Ocellated Blenny).

Clinus ocellatus Stcindachner. Ichth. Beitr., V, 1876, p. 182. Bahama Islands. Definite locality not given.

Malacoctenus biguttates (Cope).

Deseribed under the name of Labrisomus biguttatus in Trans. Aner. Philos. Soe., Phila., 1873, p. 4i3, from a specimen taken along New Providence. 
Auchenopterus affinis (Steindachner) (Nape-finned Blenny).

Heretofore recorded from St. Thomas and Key West; obtained by the Expedition at Governors Harbor, Eleuthera.

\section{Stathmonotus memphilli Bean (Hemphill's Blenny).}

Heretofore known only from two specimens taken at Key West; one example of this interesting form was obtained by the Expedition on the shore of Hog Island, near Nassau, June 18, 1903.

\section{Family OPHIDIIDA (Cusk Eels).}

Ophidiua sp. (Cusk Eel).

The steamer Albatross obtained a specimen at Abaco.

Family FIERASFERIDA: (Pearl Fishes).

Fierasfer affinis (Gïnther) (Pearl Fish).

This interesting species takes its common name from the habit of resorting to the shells of the pearl oyster. It has been recorded from Key Biscayne, Florida, the Tortugas, Cape Florida, New Providence, and on the west coast at Panama and Lower California. The Albatross collected it at Nassau, 1886, and the U. S. National Museum has recently received specimens collected by Dr. Hubert L. Clark at Jamaica.

\section{Family PLEURONECTIDAs (Flounders).}

\section{Platophrys maculifer (Poey) (Spotted Flounder).}

This little flounder was found by the Expedition in considerable numbers on the beach of east end of Hog Island, the Current, Eleuthera, and in Clarence Harbor, July, 1903. Taken in the seine. Poey described it from Cuba.

\section{Platophrys lunatus (Linnæus) (Peacock Flounder).}

A specimen 14 inches long of this beautiful flounder was taken by C. L. Edwards at Green Turtle Cay in 1888.

\section{Platophris ocellatus (Agassiz) (Ocellated Flounder).}

Sandy shores of the Atlantic coast from New England to Brazil.

\section{Platophris sp. (Spotted Flounder).}

A handsome specimen, $5 \frac{1}{2}$ inches long, of a flounder referable to this genus was taken by the Expedition at Tarpum Bay, July 7, 1903. 
Citharicthys spilopteres Gïnther (Whiff).

A small fish abundant along the shores of the western Atlantic from South Carolina to Brazil. Obtained by the Expedition along Eleuthera, the Current, July 5, 1903.

\section{Syaciom micrurum Ranzani (Small Flounder).}

This species belongs to the West Indian fauna. It was obtained by the Expedition in Clarence Harbor, July 15, 1903.

\section{Family SOLEIDA (Soles). \\ Achirus inscriptes Gosse.}

Taken by C. L. Edwards at Green Turtle Cay in 1888.

Fainily AULOSTOMIDA: (Trumpet-fishes).

Aulostomus maculatus Valenciennes (Trumpet Fish).

This interesting fish ranges from Bermuda and Florida southward. Several specimens were obtained by the Expedition at Clarence Harbor, July 14 and 17, 1903. Called "stalk-fish" in the Bahamas. The life colors of this fish are very pretty, forming as they do lines of cream, chocolate and black horizontal stripes. There are also numerous pearl-colored spots on the body.

Family SYNGNATHID (Pipe-fishes).

\section{Siphostoura albirostre (Heckel) (Pipe Fish).}

This species has been recorded from the coral reefs of the West Indies, ranging from Florida to Bahia. Obtained by the steamer Albatross at Abaco, Watlings Island and New Providence.

\section{Siphostoma pelagicun (Osbeck) (Pipe-fish).}

Tropical parts of the Atlantic. Obtained by the Expedition at Clarence Harbor, July 14, 1903.

\section{Siphostoma rousseau (Tíaup) (Pipe Fish).}

West Indies, known from St. Lucia and Martinique. Obtained by the Expedition between Nassau and Elbow Key, July, 1903, in seaweed taken by dip-net.

\section{Corythroichthys Cayorun Evermann and Kendall (Pipe-fish).}

Described from Key West; taken by the Expedition at Powells Point and Clarence Harbor, July, 1903. 


\section{Family HIPPOCAMPIDE (Sea Horses).}

Hippocanpus punctulates Guichenot (Sea Horse).

Tropical parts of the Atlantic, common in the West Indies. One specimen collected by the Expedition at Governors Harbor, July \%, 1903.

\section{Family BALISTIDA (Trigger-fishes).}

Balistes vetula Linnæus (Old-wife).

This important species is common in the tropical parts of the Atlantic, thronghout the West Indies and north to Florida, Bahama and Bermuda. It is a showy fish in life and the young, which are quite numerons around the coral heads of the Bahamas, add much to the beanty of the fish life seen there.

Collected and observer by the Expedition in considerable numbers at various points visited during June and July, 1903. Common in the Nassau market.

\section{Balistes chrolixexsis Gmelin (Turbot).}

Found in the tropical parts of the Atlantic, ranging northward in the Gulf Stream to the New England coast. Common in the Mediterranean. The flesh is eaten and the skin is used for polishing purposes. "Trigger-fish" and "leather-jacket" are other common names for this species. Several young specimens were taken by the Experlition in the Gulf weed north of Abaco during July, 1903.

\section{Caxthidemas acaculates (Bloch) (Rough-skinned 'I'urbot).}

So far as the records go this is a rare species. It inhabits the open ocean of the West Indies and has received the name of "ocean turbot." One specimen was obtained by the Expedition in floating gulf weed about sixty miles north of Abaco during July, 1903. Young, 15 inches long.

Family MONACANTHID.T (File-fishes).

\section{Moxicartiles spiloxotes Cope (File-fish).}

The habitat of this species is recorded as Gulf of Mexico. We obtained it on the elge of the Gulf Stream, Jume 6, 1903, not far from Cape Hatteras, and July 15 at Clarence Harbor, and east end of Hog Island, July 20, 1903. Common in the latter places.

('ixtherixes peldes (Ranzani) (Lija Colorada).

West Indies and Brazil, north to southern Florida. Obtained by the steamer Albatross at Nassau, April 23, 1886. 
AleTERA scripta (Osbeck) (Unicorn Fish).

This eurious fish. also known as " file-fish," was observed by Catesby in the Bahamas, and by Goode in Bermuda, where it was so nncommon (18\%?) that it lid not have a common name. It grows to a length of 2 or 3 feet. Observed by us at Nassau during June and July, 1903.

Family OSTRACIONTIDAE (Trunk-fishes).

LACTOPHRYs BICACD.ALIs Linnæus (Śhell-fish).

This curious. showy fish is-common to the West Indies. It was present in the Nassan market and is more or less esteemed as food. Like other members of the genus, it is sold to curiosity lunters.

\section{LACTOPHRYS TRICORNIS Tinnæus (Horn-fish).}

This species is rather common from the coast of North Carolina to Brazil. It is the "cow-fish" of Bermuda, "cuckold" of Jamaica." and "toro" of the Cubans. The fish reaches a length of 18 inches and is much esteemed as food. Obtained by the Expedition in Nassau market, June 20, 1903. The steamer Albatross collected it at Nassan and Abaco in 1886.

\section{LACTOPHRYS TRIGONes Linnæus (Trunk-fish).}

West Indies north to Key Wert, and straying to the coast of Massachusetts. Four specimens were collected by the Expedition at Clarence Harlor, July 14, 1903. The steamer Albatross obtained a specimen at Rum Cay, July, 1903.

Family TETRODONTID.E (Puffers).

SPherotdes spexgleri (Bloch) (Swell-toad).

This fish, known also as "puffer" and "tambor", is found from Florida and Texas thronghont the Wrest Indies to Rio Janeiro and eastward to the Canarics and Madeiras. Recorded by Mr. Goode from Bermuda. Obtained by the Expedition at the Current, Powells Point, Clarence Harbor and at east end of Hog Island, July, 1903.

\section{Family DIODONTID.T (Porcupine Fishes).}

Diodon hystrix Linnæus (Poreupine Fish).

This species is widely distributed, being found in tropical seas, everwhere more or less common. Its chief value is as a curiosity, and it is solel by dealers of marine curios. Many dried and inflated skins were seen in the shops at Nassan, ranging in length from 1 to ? feet. In Bermuda, Mr. Goode salys, 
it is highly prized by curiosity hunters, but never eaten. He records the name "sea hedgehog," and if I remember correctly, the name "edgehog " is used in the Bahamas.

Diodon holacanthus Linnæus (Smaller Poreupine Fish).

Found in warm seas generally. Tery similar to D. Thystrix, and it seems to us probably the young of that species. Numerous specimens were obtaines by the Expedition at Clarence Harbor and at the east end of Hog Island, July, 1903.

Chilomycteres spixoses (Linnæus) (Burr-fish).

Under this we would place C.schcpfi of Walbaum and C.geometricus (Bloch and Schneider). Habitat Atlantic coast of America from Cape Cod to Brazil; Gulf of Mexico to Bermuda. Taken by the steamer Albatross at Nassau, April 10, 1886.

\section{Family ANTENNARIIDA (Anglers).}

Axtexnarius principis (Cuvier and Talenciennes) (Black Angler).

West Indian fauna. Named for Prince Maurice of Nassan, its discoverer. A very small example of this interesting little fish was picked ont of some grass on the beach at Golding Key, Andros Island, June 2i, 1903, by Mr. C. A. Shore, of the botanical party. Its general color is black; spinons dorsals and tips of pectorals whitish; a white blotch on back before rars of dorsal, and upper edge of caudal peduncle whitish.

\section{Artennarius nuttixgi Garman.}

Great Bahana Banks. Expedition State University of Iowa, 1893.

Pterophrine histrio (Linnæus) (Mouse Fish).

Plate $\mathrm{L} \mathrm{T}^{\top}$.

This euriously shaped fish, known also as "sargassum-fish," and " harlequin-fish." was found by the Expedition in floating seaweed (sargassum) in and near the Gulf stream from off Cape Hatteras south to Andros Island. Quite a number were taken in dip-nets as the ressel slowly sailed along; they ranged in length from one-half to three inches. Probably fifty examples were captured by different nembers of the party, who saved them as curiositics. Twenty were preserved by the writer for the National Museun. 
The colored sketch by Mr. Baldwin is a very good representation of the fish in life. The pectorals are not quite correctly drawn, the rays should be more slender and at least ten in number. One of the larger examples has eleven rays in the pectoral.

Family OGCOCEPHALIDE (Bat-Fishes).

Ogocephalts Raditus (Mitchill).

Great Bahama Banks. Fixpedition of State University of Jowa, 1893. 



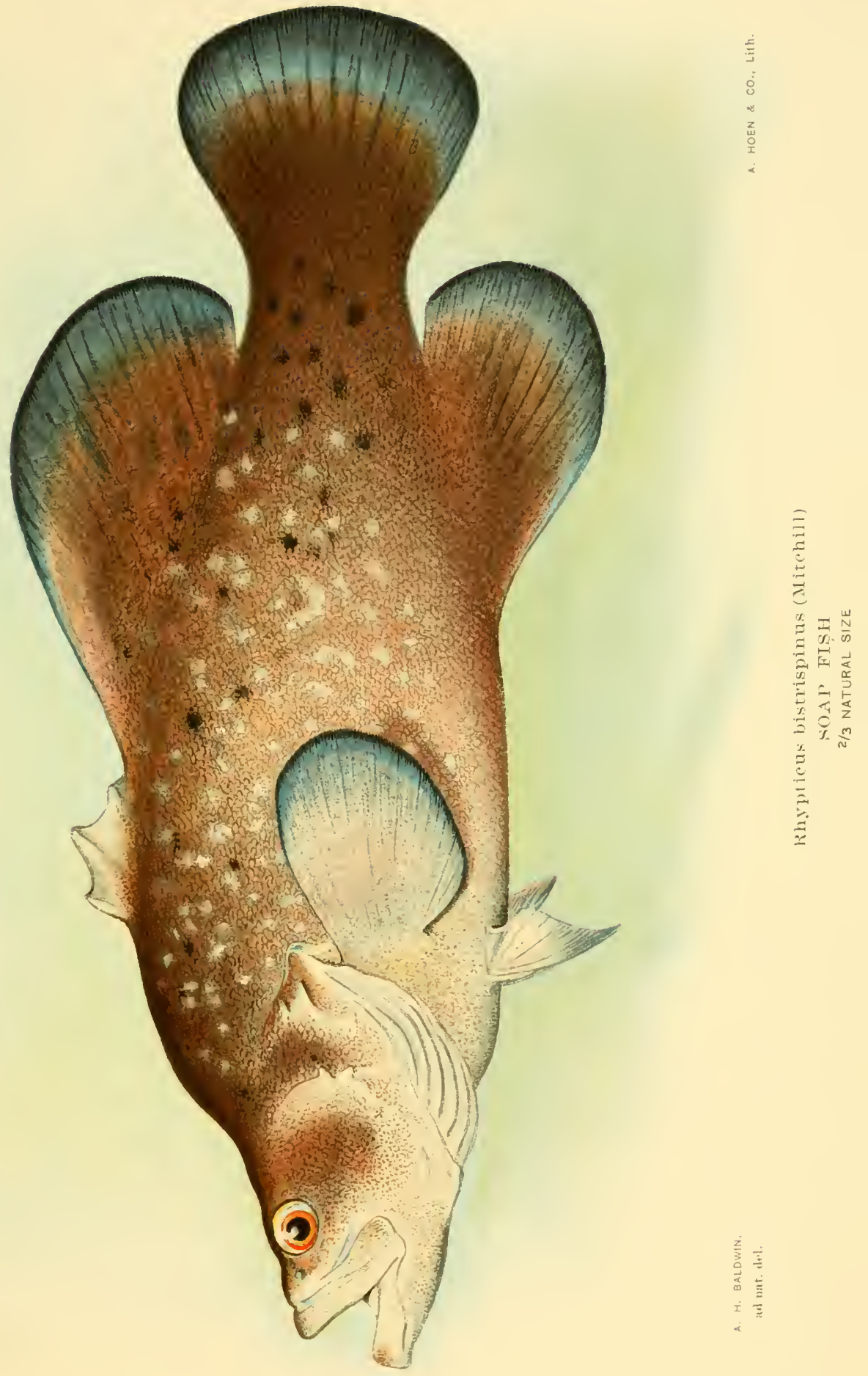







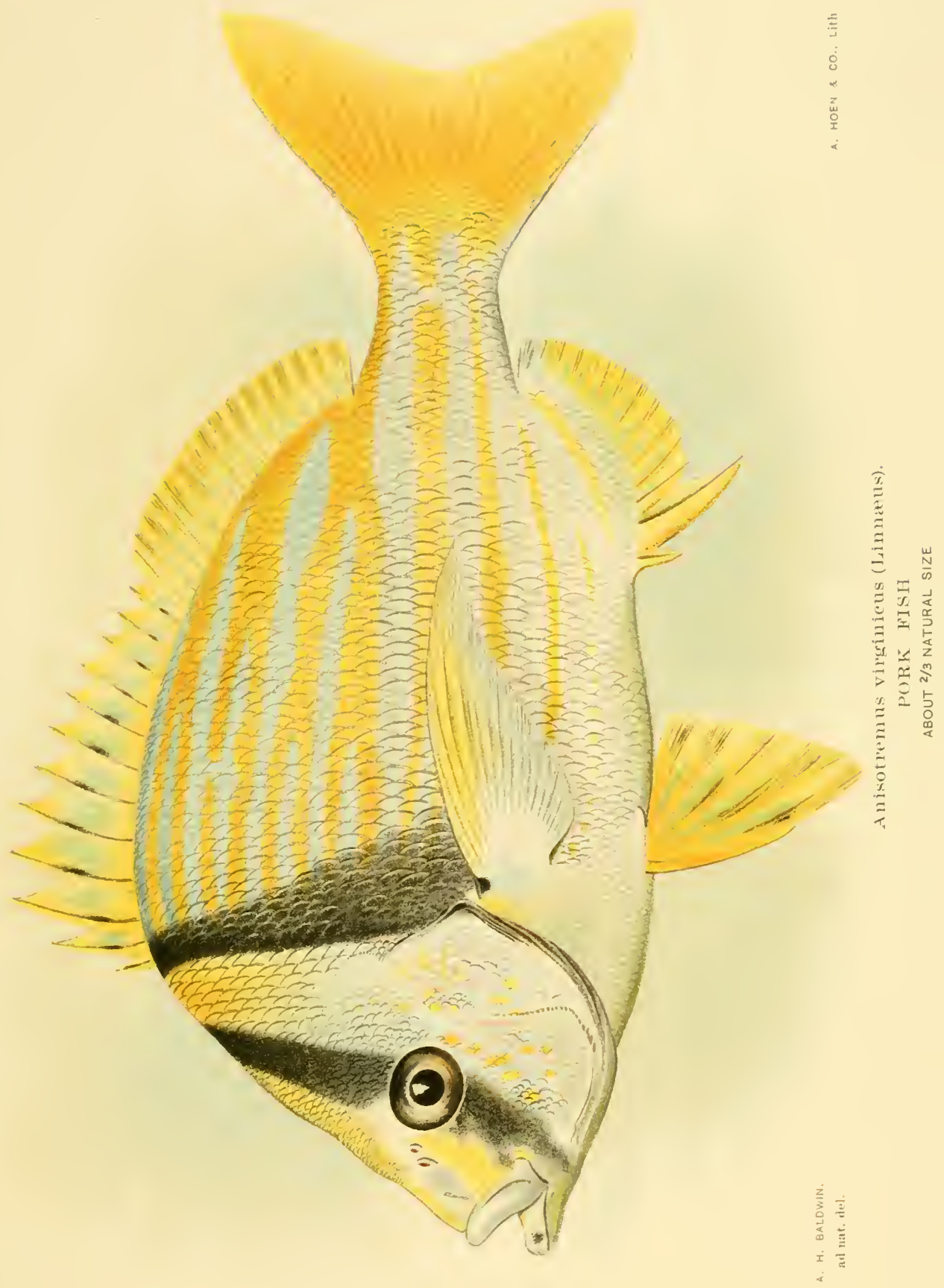





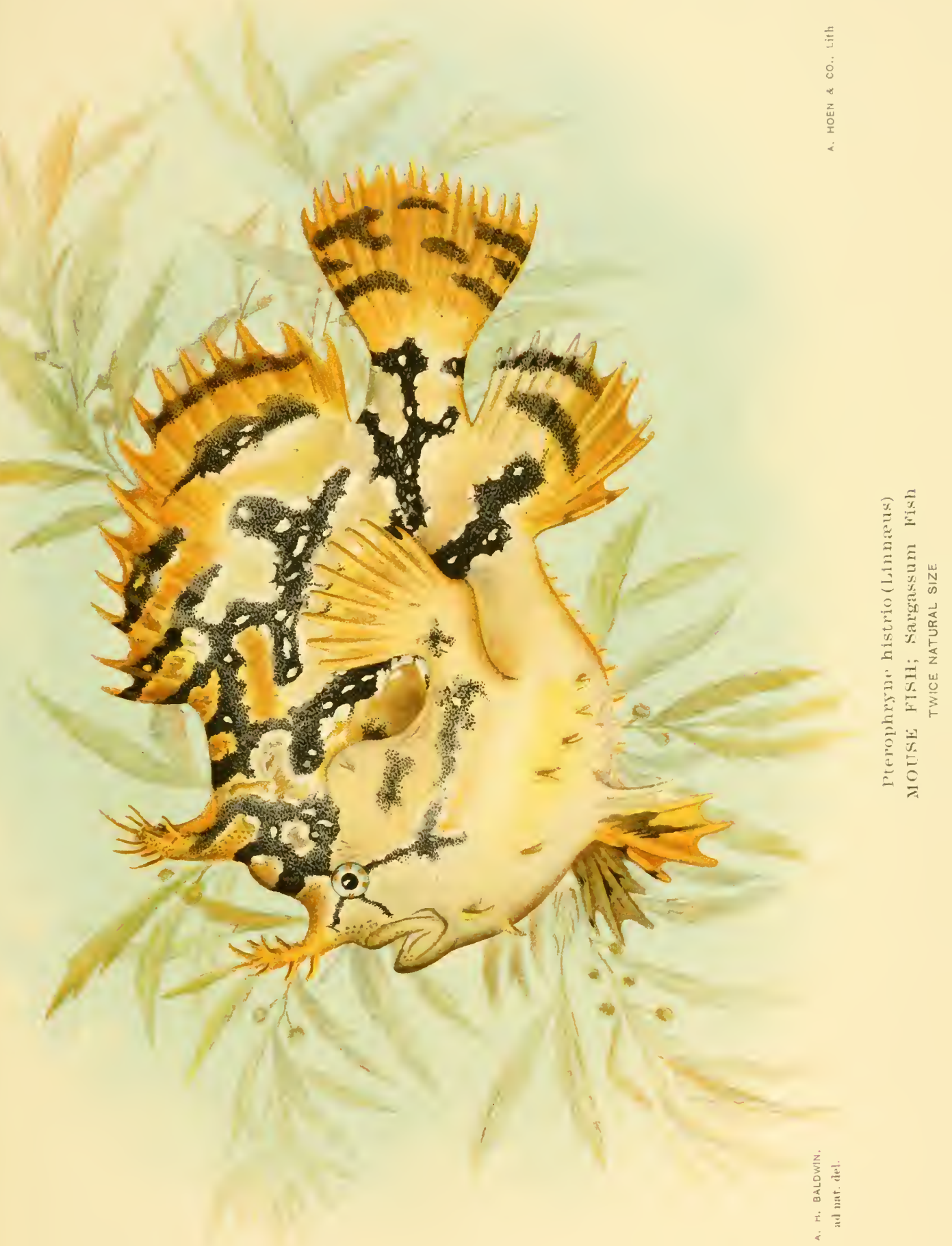





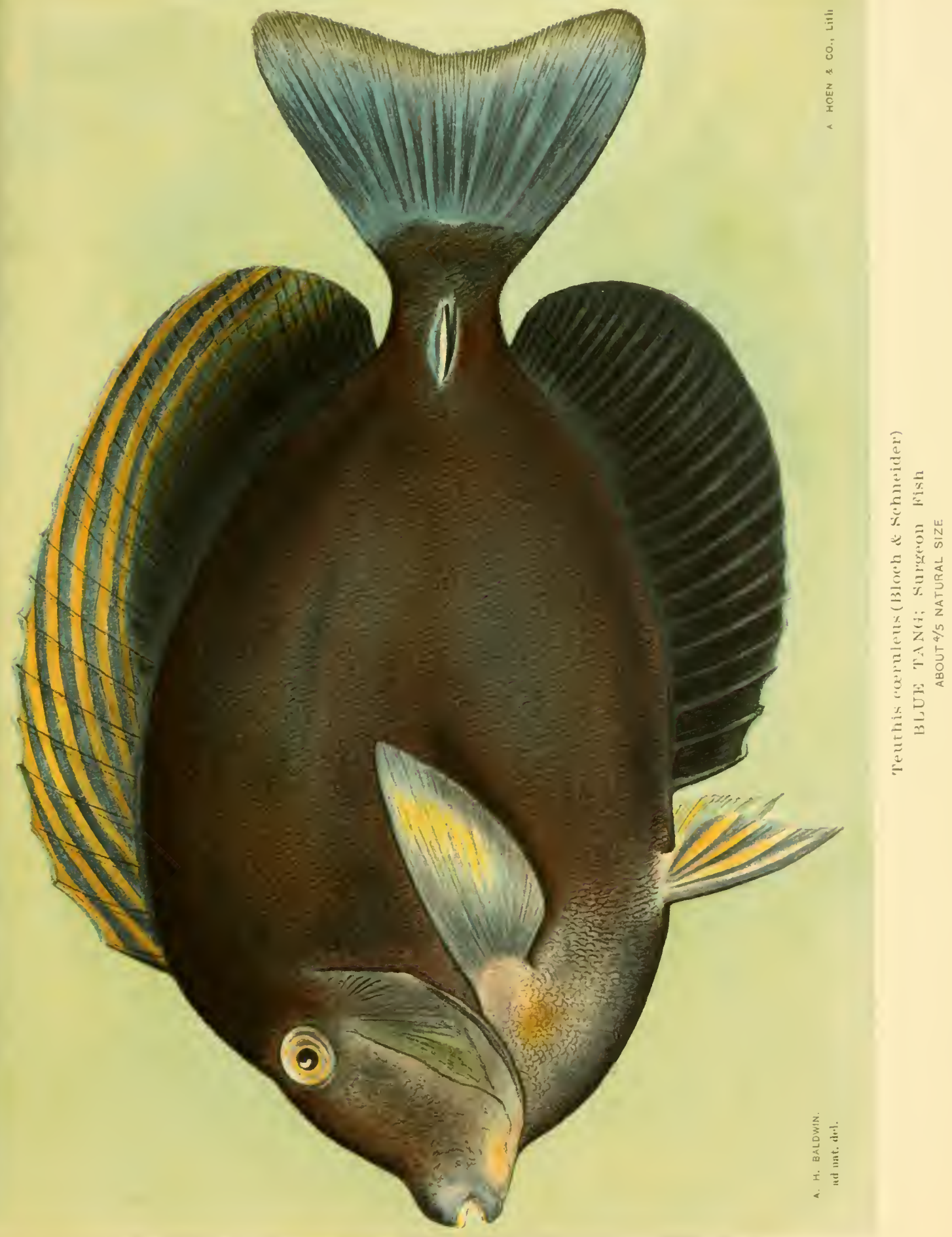





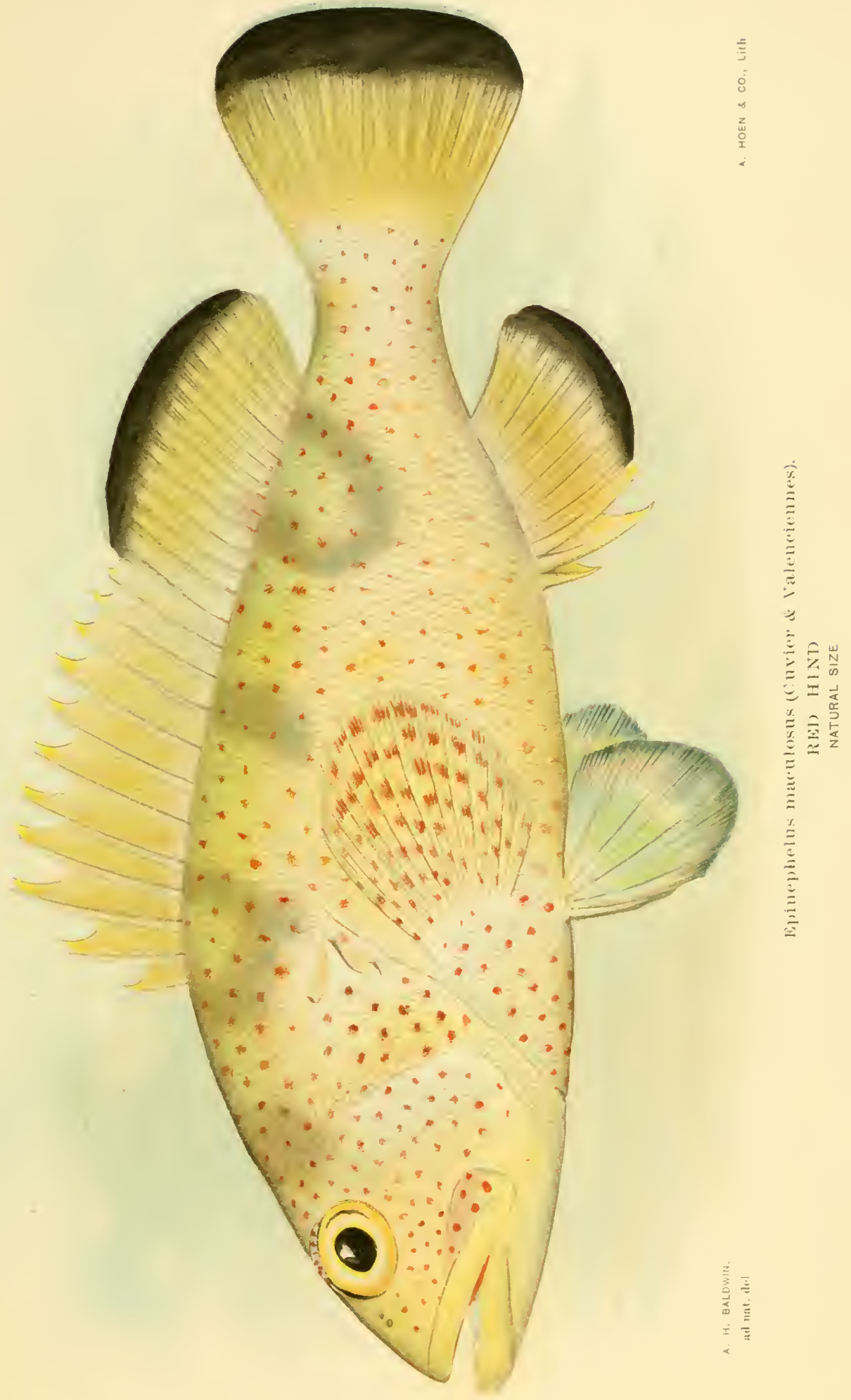





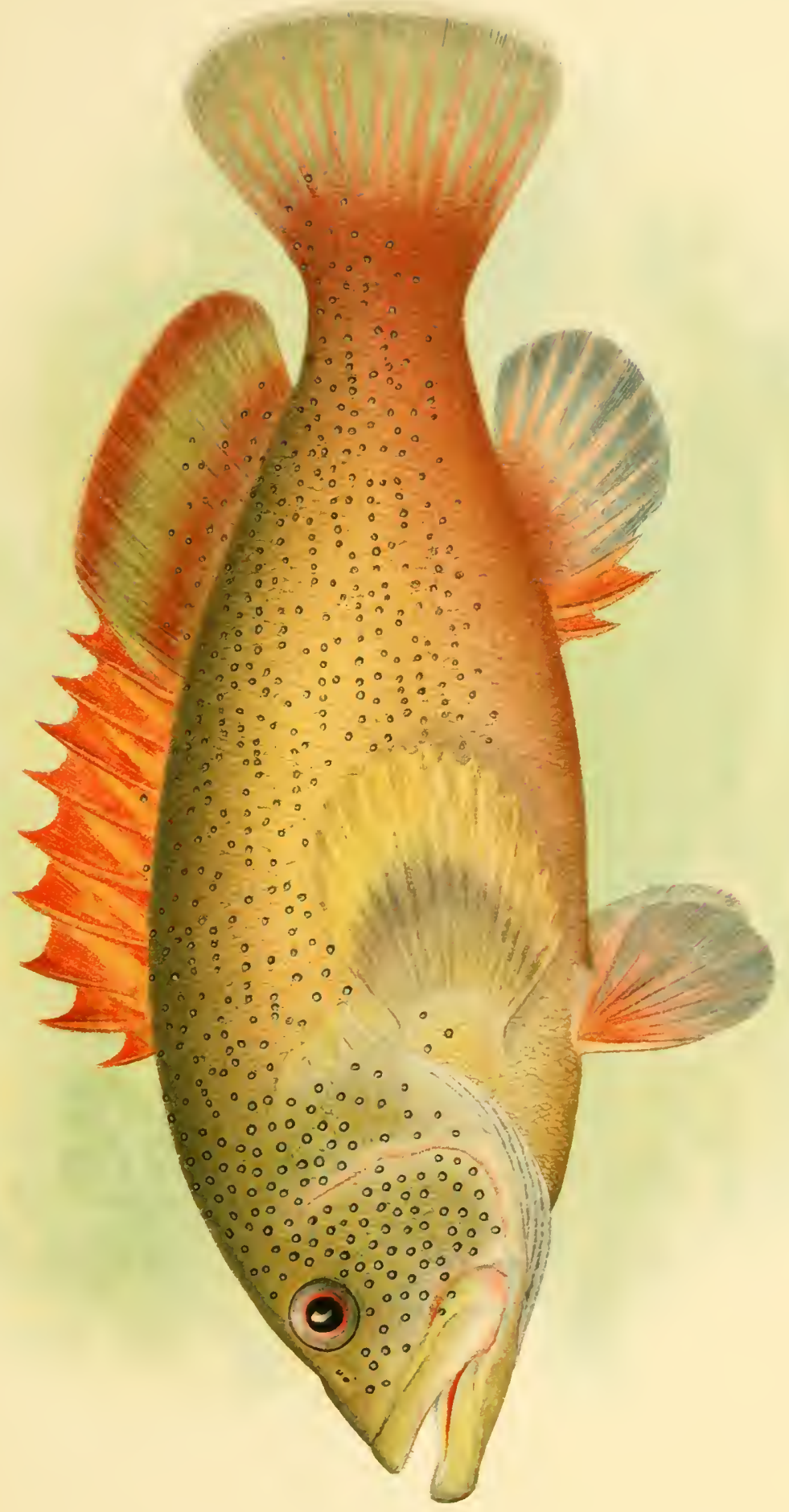





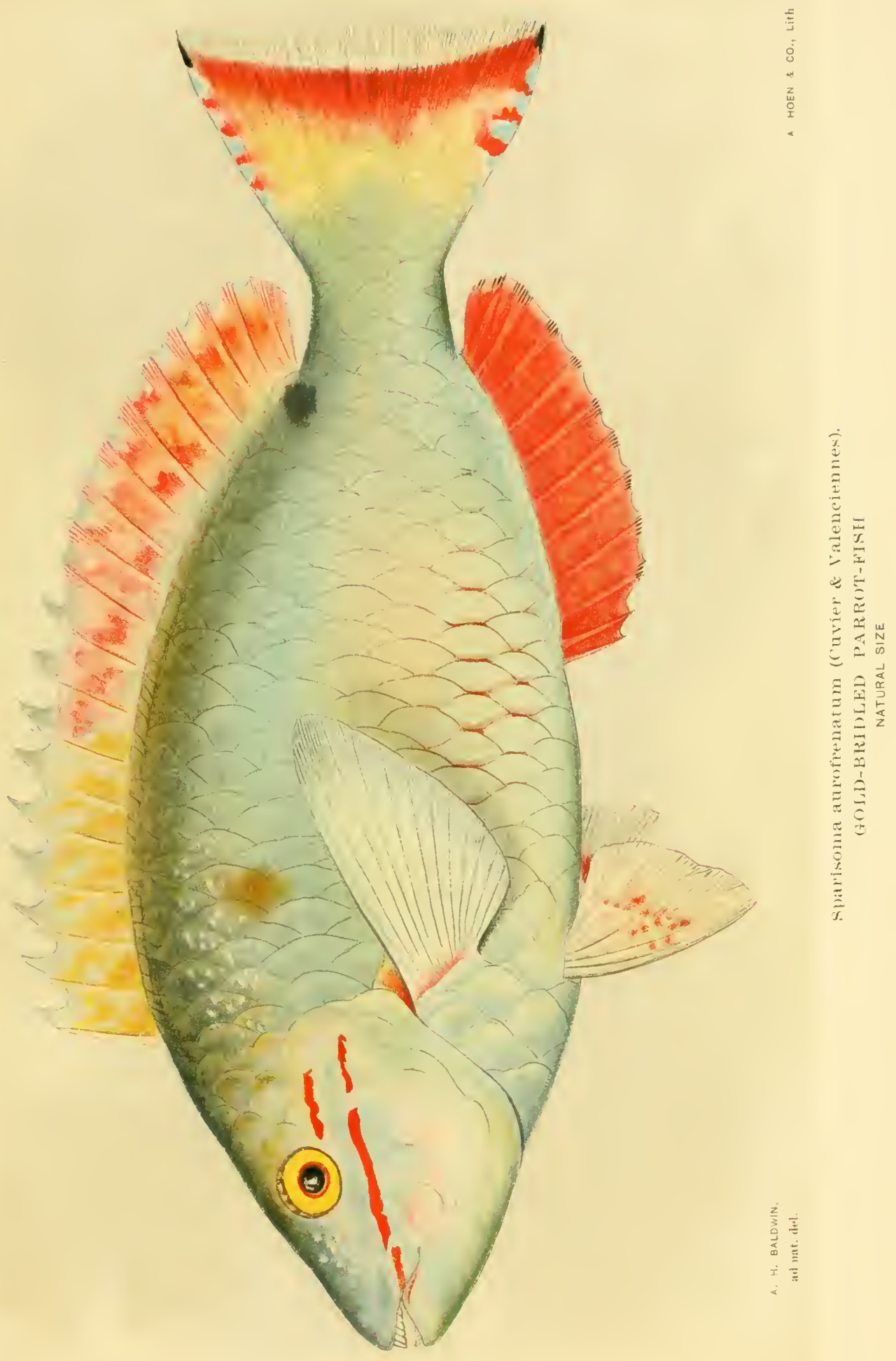





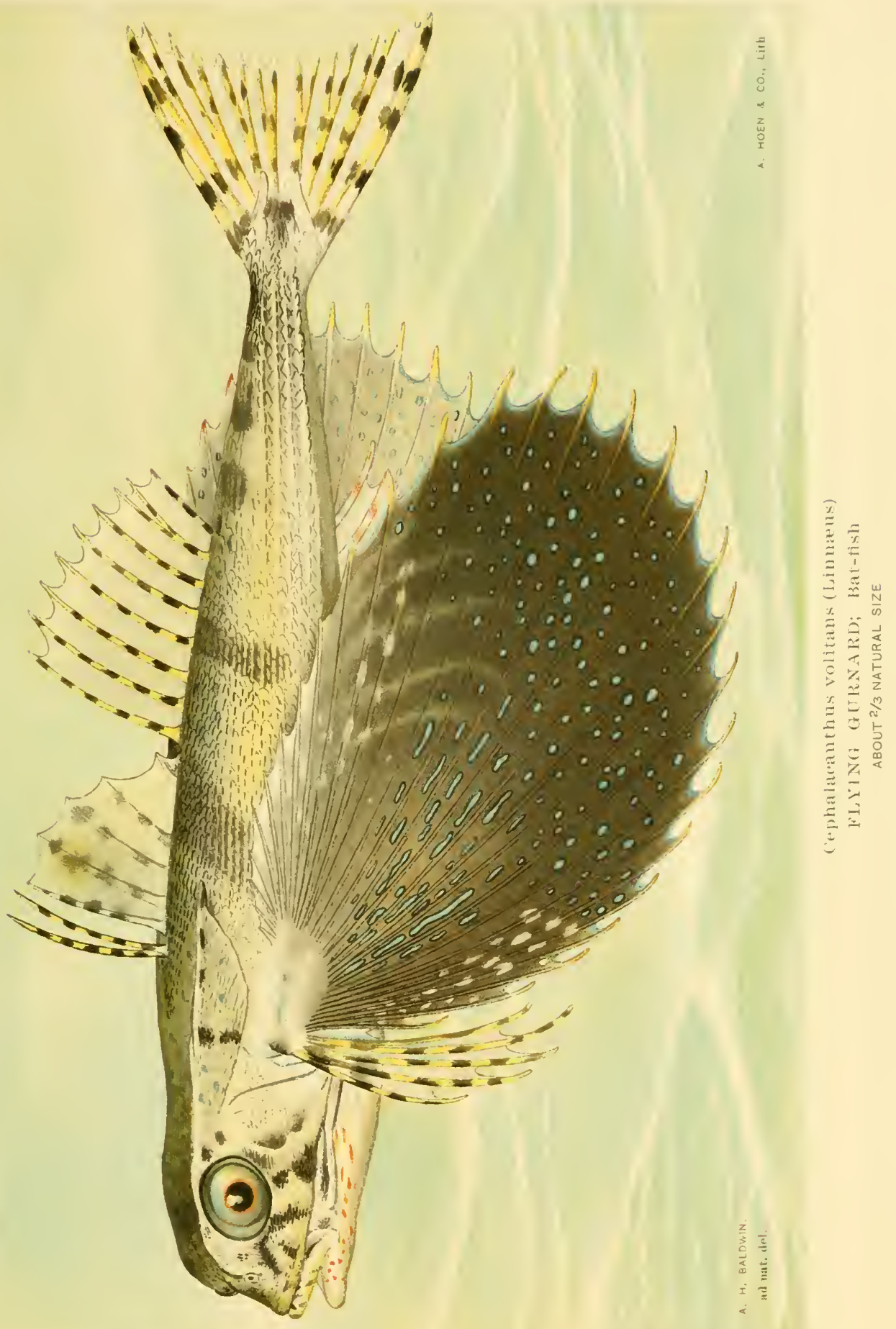





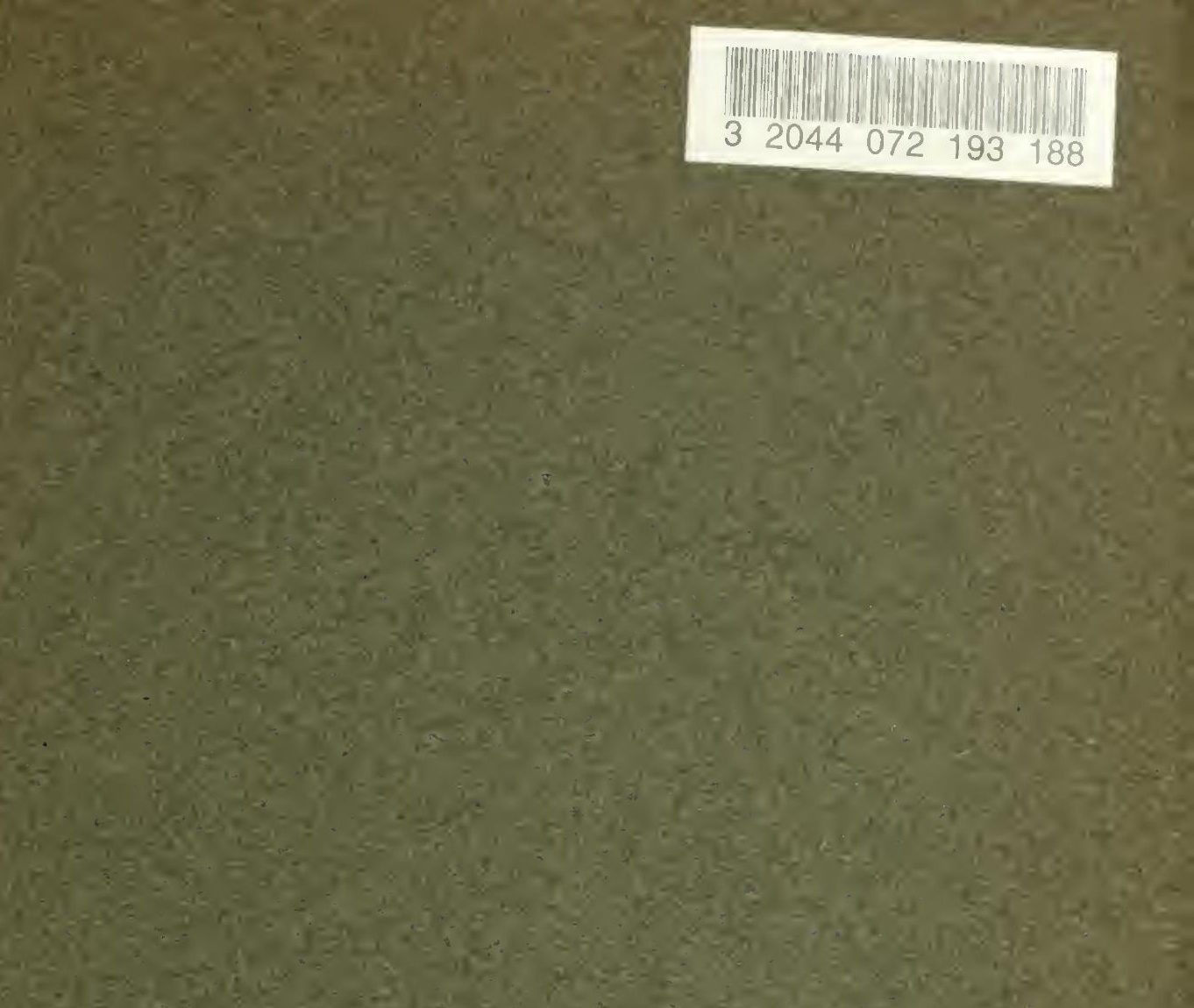

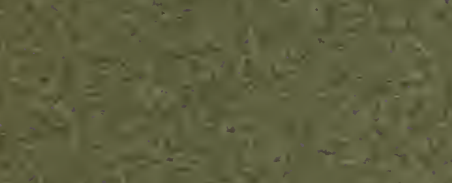




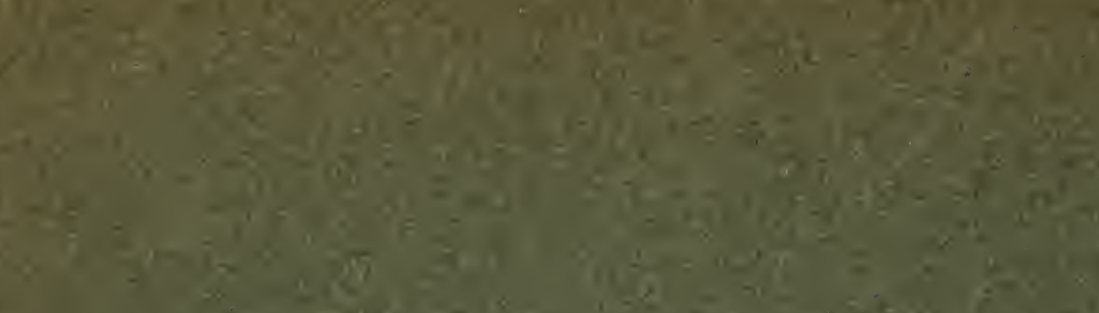

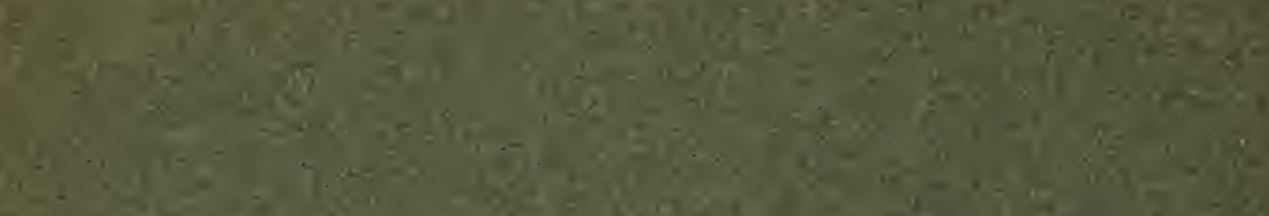

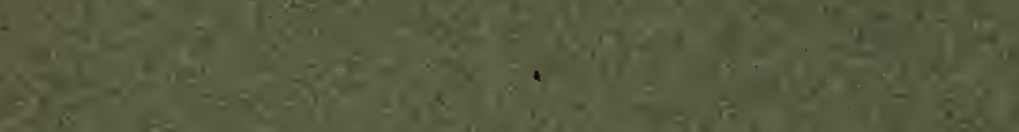

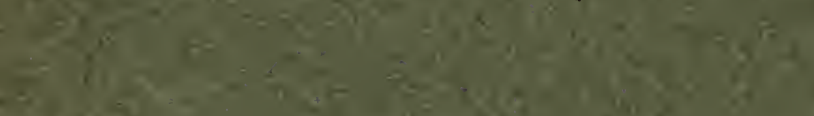

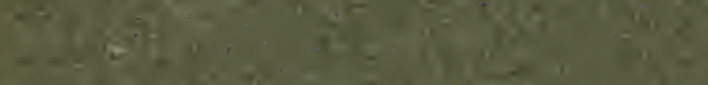

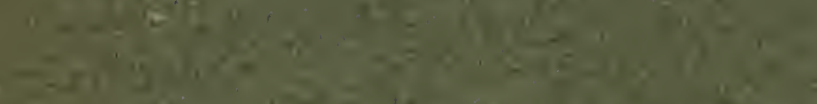

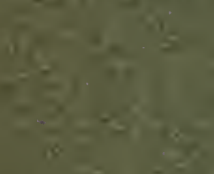

$1 \frac{10}{10}$

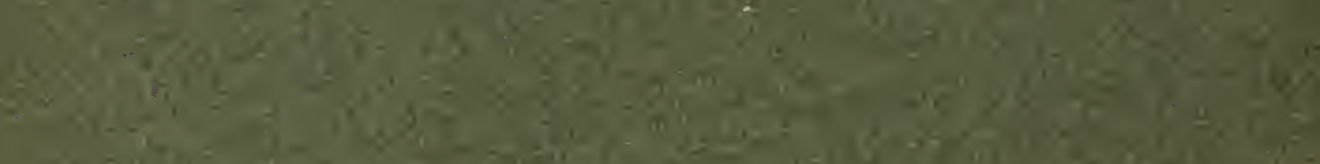

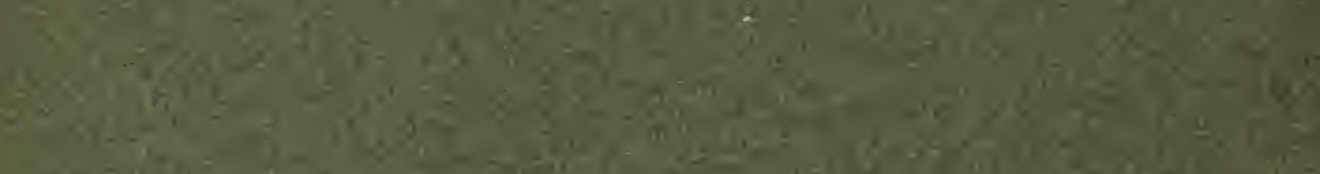

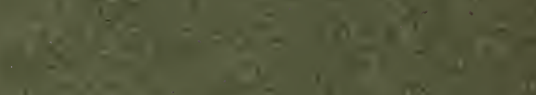

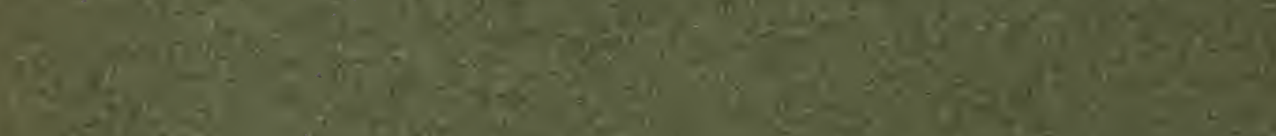

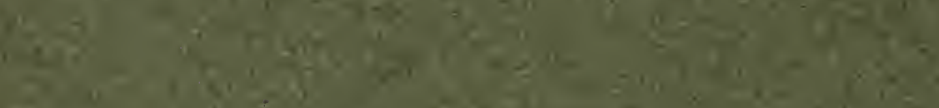

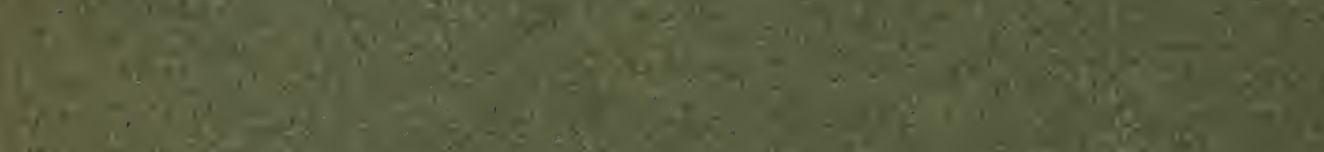

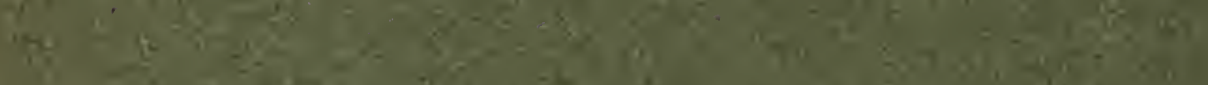

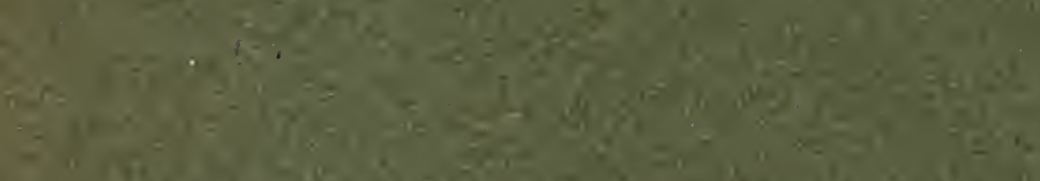

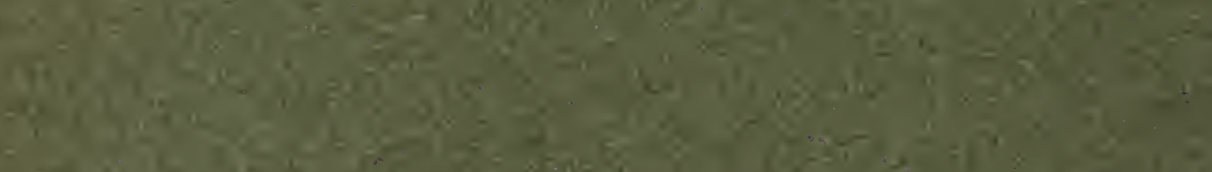
7.

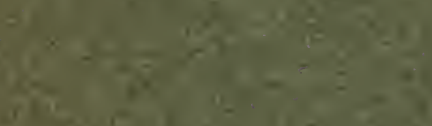

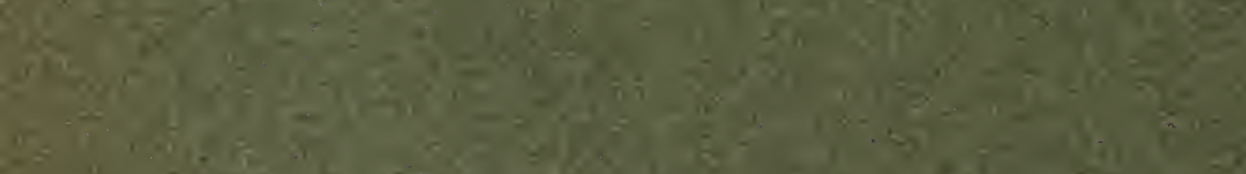

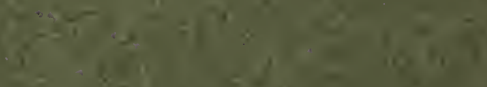

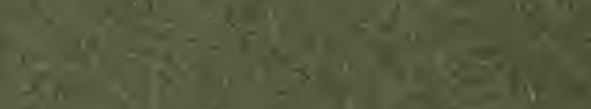

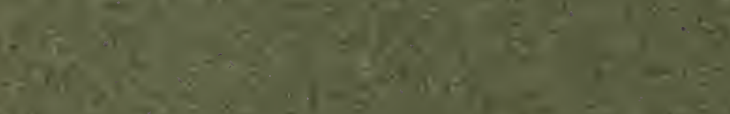

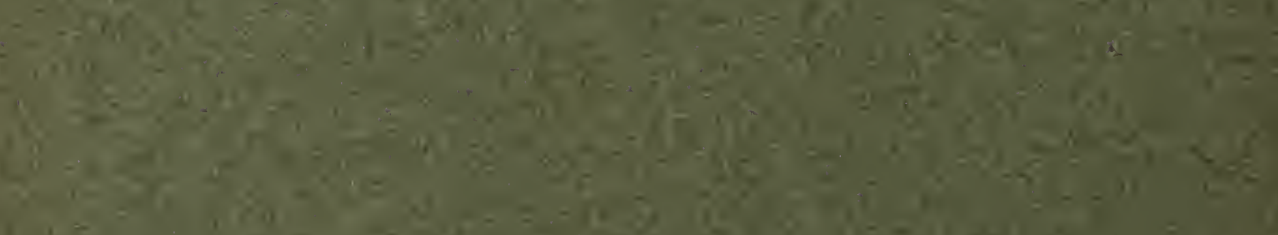

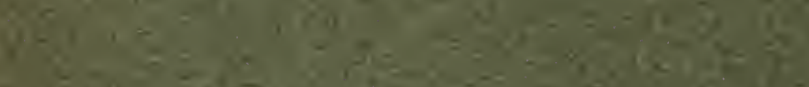

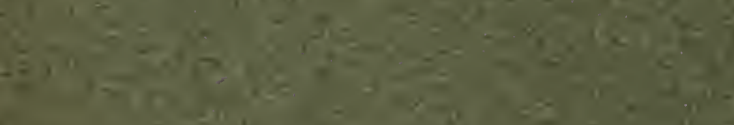

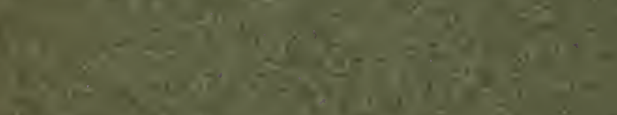

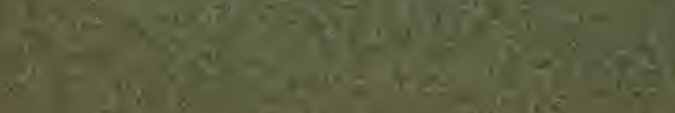

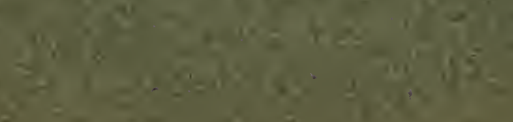

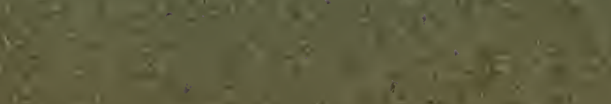

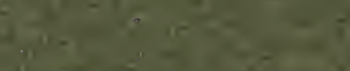



